\title{
Metal loading assessment of a small mountainous sub-basin characterized by acid drainage_Prospect Gulch, Upper Animas River Watershed, Colorado
}

By Laurie Wirt ${ }^{1}$, Kenneth J. Leib ${ }^{2}$, Roger Melick ${ }^{1}$, and Dana J. Bove ${ }^{1}$

Open-File Report 01-0258

2001

\section{Online version 1.1}

http:/geology.cr.usgs.gov/pub/open-file-reports/ofr-01-0258

This report is preliminary and has not been reviewed for conformity with U.S. Geological Survey editorial standards or with the North American Stratigraphic Code. Any use of trade, firm, or product names is for descriptive purposes only and does not imply endorsement by the U.S. Government.

\section{U.S. DEPARTMENT OF THE INTERIOR U.S. GEOLOGICAL SURVEY}

\footnotetext{
${ }^{1}$ U.S. Geological Survey, Denver, CO

${ }^{2}$ U.S. Geological Survey, Grand Junction, CO
} 
Version 1.1

October, 2001 


\section{CONTENTS}

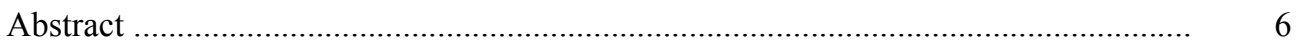

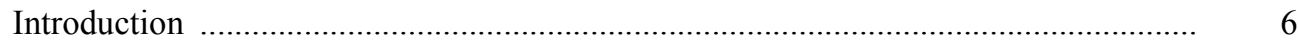

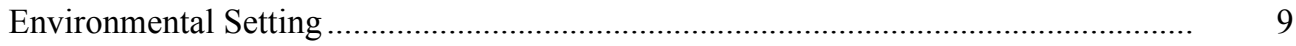

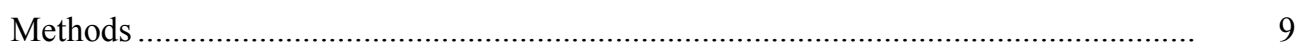

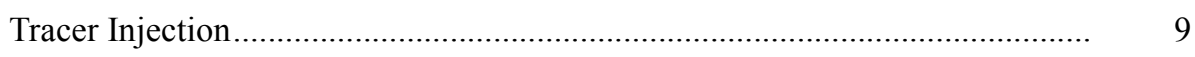

Selection of Water-Quality Sampling Locations .................................................. 13

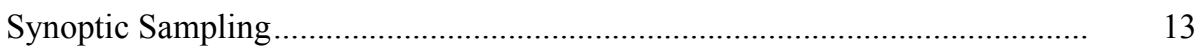

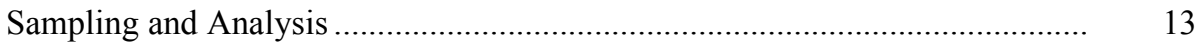

Quantification of Discharge ....................................................................... 13

Quantification of Loads ................................................................................. 13

Sampled instream load .................................................................... 18

Cumulative instream load................................................................ 18

Cumulative inflow load .................................................................... 18

Results and Discussion ..................................................................................... 18

$\begin{array}{ll}\text { Discharge } & 18\end{array}$

$\begin{array}{ll}\text { Field Reconnaissance Chemistry } & 18\end{array}$

Ground-water Age and Fracture Controls on Hydrology 19

Metal Concentrations and Load Profiles by Reach $\quad 21$

Beginning of study reach to PG153 …............................................. 23

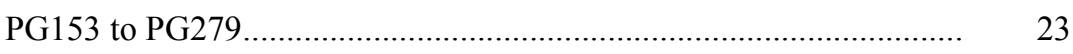

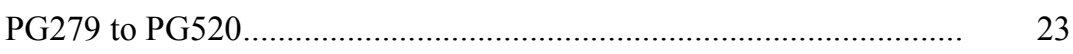

PG520 to PG800 ........................................................................ 23

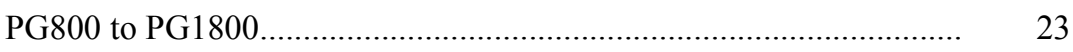

PG1800 to PG2259 …………………………………................ 23

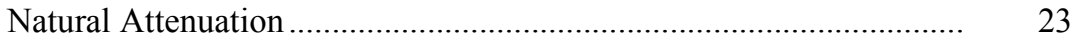

Unsampled inflows ....................................................................... 29

Principal Sources of Metal Load 29

Relation between Metal Content and Acidity 31

Acute and Chronic Water Quality Standards 31

Occurrence and Distribution of Trace Metals $\quad 31$

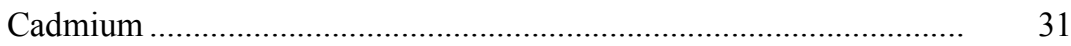

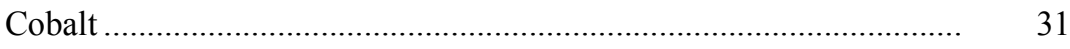

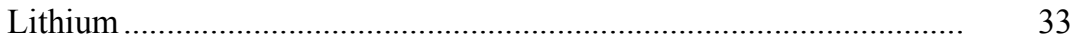

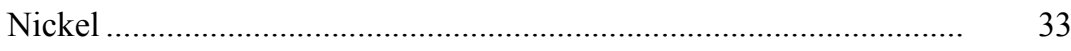

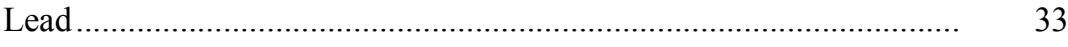

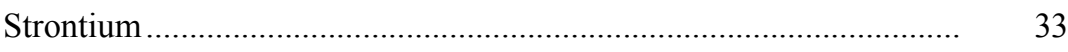

$\begin{array}{ll}\text { Conclusions } & 33\end{array}$

Acknowledgements .................................................................... 35

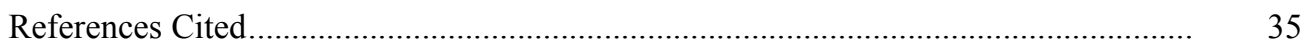




\section{LIST OF FIGURES}

1. Location map of Prospect Gulch, a tributary of Cement Creek in the upper Animas River basin, San Juan Mountains, Colorado...

2. Alteration map showing distribution of acid-producing rock types ......................... 10

3. Aerial photograph of Prospect Gulch showing water-quality sampling locations ................................................................................................ 11

4. Plots showing longitudinal profile of $\mathrm{pH}$ and specific conductance with distance downstream ............................................................................... 12

5. Plots showing longitudinal profile of chloride tracer and calculated discharge with distance downstream. ................................................................. 14

6. Three-dimensional topographic map and stream profile indicating areas of ground-water discharge. ..................................................................... 22

7. Plots showing concentration and load profile of sulfate with distance downstream

8. Plots showing concentration and load profile of aluminum with distance downstream

9. Plots showing concentration and load profile of iron with distance downstream.

10. Plots showing concentration and load profile of copper with distance downstream

11. Plots showing concentration and load profile of zinc with distance downstream.

2. Pie diagrams showing contributions of discharge and sulfate, aluminum, iron, copper, and zinc loads from selected reaches in Prospect Gulch.

3. Geochemical classification showing the relation between $\mathrm{pH}$ and dissolved metal content in mine adits, springs, tributary seeps and base flow in Prospect Gulch.

\section{LIST OF TABLES}

1. Analytical detection limits reported by laboratories used in this study.

2. Site descriptions, distance, flow type, field $\mathrm{pH}$, specific conductance, chloride tracer and major ion concentrations, Prospect Gulch, Colorado, September 1999.

3. Dissolved concentrations and cumulative instream loads of selected metals and sulfate, Prospect Gulch, Colorado, September 1999.

4. Summary of changes in discharge and cumulative instream loads by percent of reach and percent of sub-basin 


\begin{tabular}{|c|c|c|c|}
\hline Multiply & & By & To obtain \\
\hline Millimeter (mm) & & 25.4 & inch (in) \\
\hline Meter (m) & & 3.281 & foot $(\mathrm{ft})$ \\
\hline $\operatorname{Meter}(\mathrm{m})$ & & 0.001 & millimeter (mm) \\
\hline Kilometer (km) & 0.6214 & & mile (mi) \\
\hline Cubic meter per second $\left(\mathrm{m}^{3} / \mathrm{s}\right)$ & 35.31 & & cubic foot per second $\left(\mathrm{ft}^{3} / \mathrm{s}\right)$ \\
\hline Gram (g) & & 0.002205 & pound (lb) \\
\hline Kilogram (kg) & & 2.205 & pound (lb) \\
\hline Liter (L) & & 0.0001 & milliliter $(\mathrm{ml})$ \\
\hline
\end{tabular}

Millimeter per second $(\mathrm{mL} / \mathrm{s})$

Million years ago (Ma)

MicroSiemens per centimeter at 25 degrees Celsius $(\mu \mathrm{S} / \mathrm{cm})$

Milligrams per liter $(\mathrm{mg} / \mathrm{L})$

Micrograms per liter $(\mu \mathrm{g} / \mathrm{L})$

Parts per million (ppm)

Micron or micrometer $(\mu \mathrm{m})$

Degree Celsius $\left({ }^{\circ} \mathrm{C}\right)$ 


\title{
Metal loading assessment of a small mountainous sub-basin characterized by acid drainage - Prospect Gulch, upper Animas River Watershed, Colorado
}

\author{
By Laurie Wirt, Kenneth J. Leib, Roger Melick, and Dana Bove
}

\begin{abstract}
Prospect Gulch is a steep-gradient mountain catchment that is strongly affected by natural acidity from pyrite weathering. Metal content in the water column is a composite of multiple sources affected by hydrologic, geologic, climatic, and anthropogenic conditions. Identifying sources of metals from various drainage areas was determined using a tracer injection approach and synoptic sampling during low flow conditions on September 29, 1999 to determine loads. The tracer data was interpreted in conjunction with detailed geologic mapping, topographic profiling, geochemical characterization, and the occurrence and distribution of trace metals to identify sources of ground-water inflows. For this highly mineralized sub-basin, we demonstrate that $\mathrm{SO}_{4}, \mathrm{Al}$, and $\mathrm{Fe}$ load contributions from drainage areas that have experienced historical mining —although substantial—are relatively insignificant in comparison with $\mathrm{SO}_{4}, \mathrm{Al}$, and $\mathrm{Fe}$ loads from areas experiencing natural weathering of highlyaltered, pyritic rocks.
\end{abstract}

Regional weathering of acid-sulfate mineral assemblages produces moderately low $\mathrm{pH}$ waters elevated in $\mathrm{SO}_{4}, \mathrm{Al}$, and $\mathrm{Fe}$; but generally lacking in $\mathrm{Cu}, \mathrm{Cd}, \mathrm{Ni}$, and $\mathrm{Pb}$. Samples impacted by mining are also characterized by low $\mathrm{pH}$ and large concentrations of $\mathrm{SO}_{4}, \mathrm{Al}$, and $\mathrm{Fe}$; but contained elevated dissolved metals from ore-bearing vein minerals such as $\mathrm{Cu}, \mathrm{Zn}$, $\mathrm{Cd}, \mathrm{Ni}$, and $\mathrm{Pb}$. Occurrences of dissolved trace metals were helpful in identifying ground-water sources and flow paths. For example, cadmium was greatest in inflows associated with drainage from inactive mine sites and absent in inflows that were unaffected by past mining activities and thus served as an important indicator of mining contamination for this environmental setting.

The most heavily mine-impacted reach (PG153 to PG800), contributed $8 \%$ of the discharge, and $11 \%, 9 \%$, and $12 \%$ of the total $\mathrm{SO}_{4}, \mathrm{Al}$, and $\mathrm{Fe}$ loads in Prospect Gulch. The same reach yielded $59 \%$ and $37 \%$ of the total $\mathrm{Cu}$ and $\mathrm{Zn}$ loads for the subbasin. In contrast, the naturally acidic inflows from the Red Chemotroph iron spring yielded $39 \%$ of the discharge and $54 \%$, $73 \%$, and $87 \%$ of the $\mathrm{SO}_{4}, \mathrm{Al}$, and Fe loads; but only $4 \%$ of the total $\mathrm{Cu}$ and $30 \%$ of the total $\mathrm{Zn}$ loads in Prospect Gulch.
Base flow from the Prospect Gulch sub-basin contributes about 4.8 percent of the total discharge at the mouth of Cement Creek; compared with sampled instream loads of $1.8 \%, 8.8 \%$, $15.9 \%, 28 \%$, and $8.6 \%$ for $\mathrm{SO}_{4}, \mathrm{Al}, \mathrm{Fe}, \mathrm{Cu}$ and $\mathrm{Zn}$, respectively. Water-shed scale remediation efforts targeted at reducing loads of $\mathrm{SO}_{4}, \mathrm{Al}$, and $\mathrm{Fe}$ at inactive mine sites are likely to fail because the major sources of these constituents in Prospect Gulch are predominantly discharged from natural sources. Remediation goals aimed at reducing acidity and loads of $\mathrm{Cu}$ and other base metals, may succeed, however, because changes in $\mathrm{pH}$ and loads are disproportionately greater than increases in discharge over the same reach, and a substantial fraction of the metal loading is from mining-impacted reaches. Whether remediation of abandoned mines in Prospect Gulch can be successful depends on how goals are defined-that is, whether the objective is to reduce loads of $\mathrm{SO}_{4}, \mathrm{Al}$, and $\mathrm{Fe}$; or whether loads of $\mathrm{Cu}$ and other base metals and $\mathrm{pH}$ are targeted.

\section{INTRODUCTION}

Assigning metal loads in a stream to a particular point source, such as a mine adit or a non-point source (such as a mineralized rock unit or waste-rock dump), is difficult to demonstrate conclusively for a variety of reasons. The distribution of ore deposits is highly variable; a mined watershed typically includes drainage from more than one mine; and near-surface hydrologic conditions may vary greatly with climate, topographic gradient, and the underlying geologic terrain. In mineralized settings, natural weathering of pyrite can be a major source of metal loading to streams; however, few near-surface ore deposits of any consequence remain in their "natural" condition, undisturbed by human activity. Metal loading is exacerbated by human disturbance of mineral deposits, but to what degree in any given environmental setting? instream metal concentrations generally are a composite of multiple sources affected by a myriad of environmental conditions.

Moreover, ground-water and surface-water inflows with the highest concentrations of metals are often small in discharge, and hence, do not always produce the largest metal loads. Thus, relying on metal concentrations of solid-phase samples from waste-rock dumps and water-quality samples from adits to prioritize sites for cleanup can be misleading 
(Nash, 1999). A more diagnostic tool is the tracer-injection method that can relate the metal loads in a stream to specific drainage areas that generate metals. This method combines the use of a steady-state tracer injection to measure discharge (Rantz, S.E., and others, 1982; Bencala and others, 1990; Kimball, 1997) coupled with synoptic sampling to determine detailed spatial variations in stream chemistry (Bencala and McKnight, 1987). Discharge and chemistry are then combined to produce a detailed profile of the metal load for the watershed (Kimball and others, 1994; 2000; 2001).

Efforts to improve water quality in the upper Animas River watershed by reclaiming abandoned mine sites have targeted Prospect Gulch for detailed study (Wirt and others, 1999 and 2000; Bove and others, 2000; Herron and others, 1998; Nash, 1999) because several abandoned mines and waste-rock dumps in Prospect Gulch are located on Federal land, and information is needed by the BLM to assess the relative degree of contamination from point and non-point sources of metals. Information on sources and loading of metals will be used to prioritize remediation and to develop strategies for cleanup. Mining-related sources of metals in Prospect Gulch include overland flow from mine adits, surface drainage from abandoned mine sites, and seepage through waste-rock dumps. Metals and acidity also are derived from natural weathering of pyrite, which may be as high as 10 percent by weight in the highly altered and mineralized volcanic bedrock (Yager and Quick, 1993).

In this paper, metal-bearing ground-water inflows to Prospect Gulch were first delineated using tracer injection techniques and then correlated to their mineral source by integrating available hydrologic, geologic, and geochemical information. The principal objective of this effort was to identify inflows bearing the largest metal loads and then to deduce the most probable source(s) of metals by examining both hydrologic drainage patterns and mineral assemblages in the ore and bedrock to infer ground-water flow paths. Both deep and shallow ground-water sources were considered. Stream reaches likely to produce gradual, diffuse gains inflow from shallow drainage through unconsolidated surface materials-including alluvium, soil, and rock talus-were inferred on the basis of slope and topography. Shallow, diffuse inflows were assumed to have a higher degree of seasonal variability and may be negligible or absent during low flow conditions. In contrast, discrete gains from the largest perennial inflows usually occurred over short reaches (i.e. less than 100 meters) and their locations generally coincided with mapped faults or fractures in bedrock. Deeper ground-water inflows are generally perennial with a lesser degree of seasonal variability than shallow sources.

Concentrations of dissolved metals were related to geologic distribution of regional mineral alteration assemblages and veintype ore deposits, as well as to sites of mining activity. For example, the presence of certain trace metals was evidence that ground water had been in contact with a specific mineralized vein deposit or mineral-alteration type. The goal of this multidisciplinary approach is to provide a more detailed watershedbased assessment of the effects of local mining to assist decisions about remediation.
This study was conducted as part of the U.S. Geological Survey's (USGS) Abandoned Mine Lands (AML) initiative and in cooperation with the Bureau of Land Management (BLM) to identify sources of metals to the stream and to measure chemical-constituent loads during base-flow conditions. The Prospect Gulch sub-basin is a substantial contributor of sulfate, iron, aluminum, zinc, and other metals to Cement Creek, a major tributary of the upper Animas River in southwestern Colorado (Fig. 1) that is known for its reddish-orange color, high metal content, and acidity. Prospect Gulch is a surface-water point source of metals to Cement Creek, however, diffuse ground-water inflows from sedge-grass wetlands and iron bogs upstream and downstream from the mouth of Prospect Gulch also contribute substantially to metal loads in the same reach of Cement Creek (Kimball and others, in press). More information is needed about the hydrologic relation between Prospect Gulch and these non-point source inflows. In 1996, Kimball and others (in press) assessed metal loads in Cement Creek using tracer-injection and synoptic sampling techniques. This study is intended to compliment earlier efforts and to advance the goals of the USGS Abandoned Mine Lands Initiative (Nimick and Von Guerard, 1998) by providing more site-specific detail at the subbasin scale.

\section{APPROACH}

In this study we apply tracer injection methods and synoptic sampling to the $4.4 \mathrm{~km}^{2}$ Prospect Gulch watershed in order to distinguish among distinct sources and ground-water inflows that contribute metals to base flow in the stream. We also integrate available hydrologic, geologic, and geochemical information developed within the AML program to provide a more complete understanding of metal transport at the sub-basin scale. Using discharge and load profiles, we identified and quantified loads for (1) discrete inflow sources which emanate from undisturbed as well as previously mined areas; (2) diffuse or non-point sources that cannot be sampled directly; and (3) estimated the relative contribution from each major source along the stream profile. Finally, we considered these inflows in light of the following site-specific information:

1) Detailed geologic mapping of hydrothermal alteration assemblages that spatially relate differences in water chemistry to specific drainage areas.

2) Evaluation of the steep-gradient topography and fracture patterns to infer the source of ground-water inflows and areas where ground-water recharge is likely.

3) The presence of dissolved trace metals in ground-water and tributary inflows was used to infer the source of drainage and the extent of contact with vein minerals and mine drainage.

4) Plots of $\mathrm{pH}$ versus the sum of dissolved trace metals provide a conceptual framework to support the assessment.

Thus, multiple lines of evidence were used to supplement the linear loading profiles developed from the tracer data to provide an integrated watershed-based assessment of the sub-basin. 

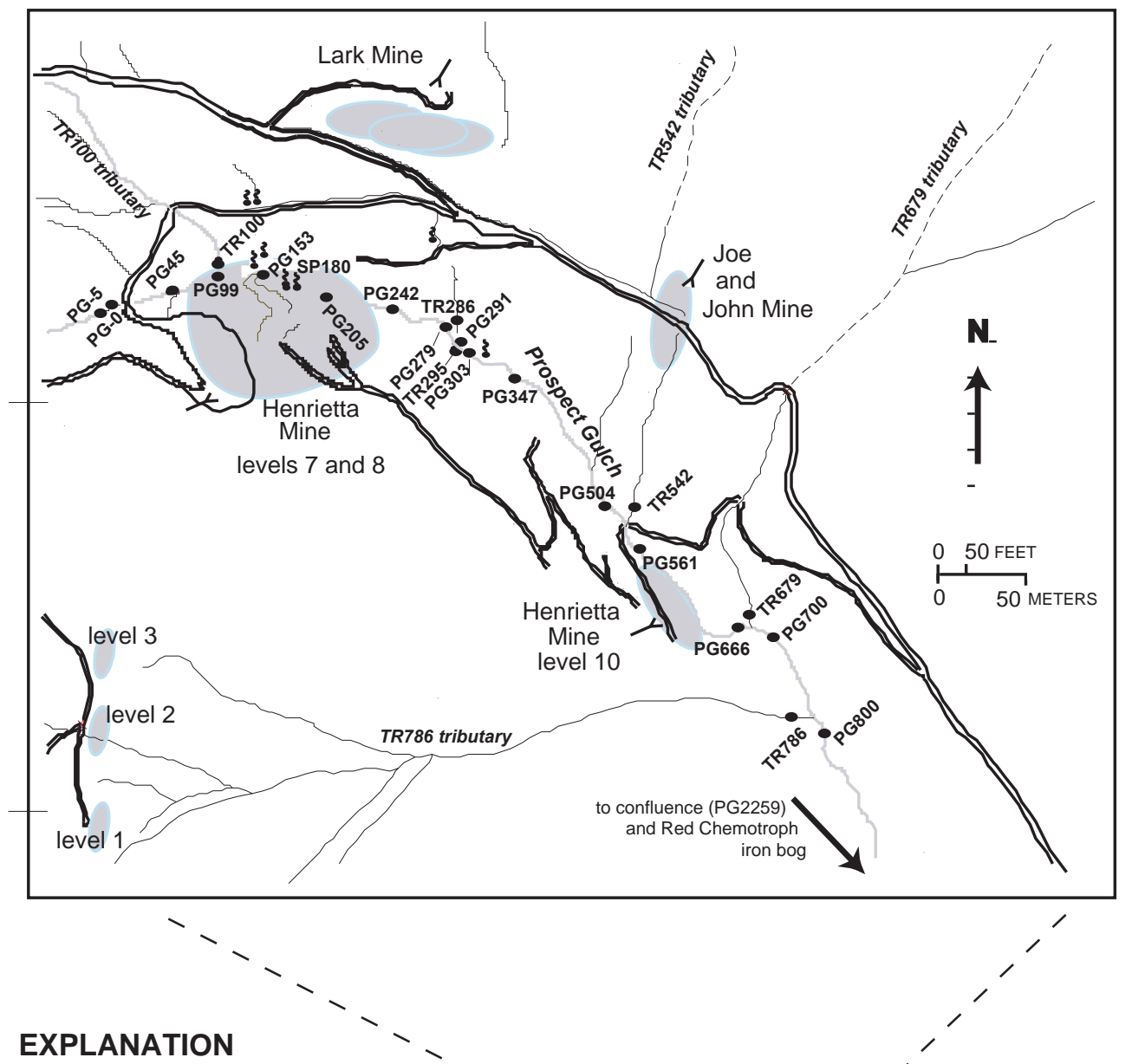

\section{EXPLANATION}

\ mine adit

- TR100; SITE name listed in Table 2.

waste-rock dump

stream or tributary drainage

$=$ unimproved road

s spring

C

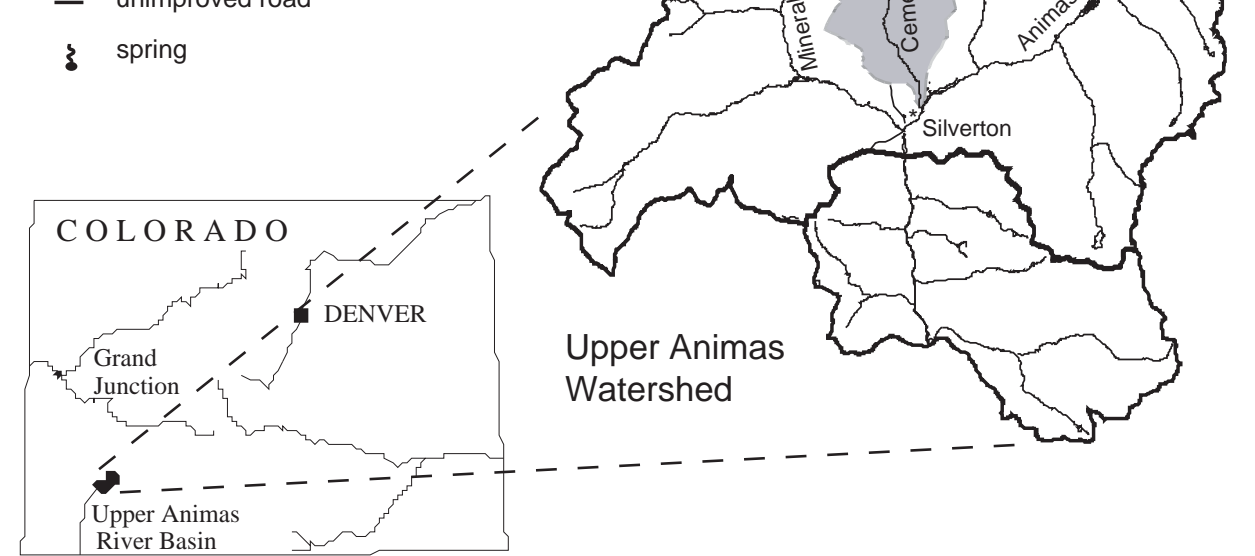

$$
\text { LOCATION MAP }
$$

Figure 1. Location of Prospect Gulch study Reach, upper Animas River watershed, southwestern Colorado. Shaded areas in "A" have been disturbed by mining. 


\section{ENVIRONMENTAL SETTING}

Prospect Gulch is a steep-gradient mountain stream that drains the southern flank of highly-mineralized Red Mountain No. 3 (elevation 3,930 m or 12,890 ft). The southern and western parts of the sub-basin have largely undergone regional or propylitically hydrothermal alteration, shown in Fig. 2. The northern third of the sub-basin is more highly altered and is dominated by several distinct suites of acid-sulfate alteration assemblages. The stream is approximately $2.4 \mathrm{~km}(1.5 \mathrm{mi})$ long and joins Cement Creek about $1.6 \mathrm{~km}(1 \mathrm{mi})$ downstream from Gladstone. Much of the Prospect Gulch drainage basin is above the tree line at about 3,536 $\mathrm{m}(11,600 \mathrm{ft})$. Non-forested areas consist of exposed bedrock or alpine vegetation on poorly developed soils. Average annual precipitation is about $114 \mathrm{~cm}$ (45 in) with $94 \mathrm{~cm}$ (37 in) occurring as snowfall (Sunnyside Gold Corporation, written commun., 1996, as cited in Herron and others, 1998). Peak runoff typically occurs from snowmelt in May and June. Runoff from thunderstorms is highly variable, but most likely to occur during the summer monsoon from July through early September. The best opportunity to identify and quantify ground-water inflows is late summer, following the monsoon season and before the first snowfall.

Prospect Gulch lies within the Silverton caldera, which is described by Burbank and Luedke (1969), and Lipman and others (1973 and 1976). Volcanic rocks in the Prospect Gulch watershed consist predominantly of massive andesitic and dacitic flows, flow breccias, and volcaniclastic sediments (Burbank and Luedke, 1969). The northern slopes of Prospect Gulch (Fig. 2) encompass the margins of an extensive acid-sulfate hydrothermal system comprised of quartz-alunite + pyrophyllite altered rocks $(0.6 \mathrm{mi} 2)$, and paragenetically older but related quartzsericite-pyrite alteration (Bove and others, 1998; 2000). The altered rocks in these spectacular red-and-bleached-tan-colored talus slopes contain 8-10 volume percent pyrite and as much as 1,100 parts per million (ppm) copper $(\mathrm{Cu}), 200 \mathrm{ppm}$ zinc $(\mathrm{Zn})$, and $60 \mathrm{ppm}$ lead $(\mathrm{Pb})$ (Yager and Quick, 1993). Weathering of highly altered rocks is believed to contribute substantially to the low $\mathrm{pH}$ and high metal loads in Prospect Gulch (Bove and others, 1998). In contrast, rocks in the southern part of the basin comprised of chlorite, epidote, and calcite represent a much weaker regional propylitic event that was largely unaffected by a later generation of acid-sulfate altering fluids. Thus, rocks on the south side of the sub-basin provide relatively greater acid neutralizing capacity than rocks exposed on the north slopes at higher elevations.

The tracer injection focused in detail on an 800-m reach of Prospect Gulch (PG-0 to PG800) that includes drainage from at least 4 mine adits and several large waste dumps from 3 abandoned mine sites on BLM property-the Lark, Henrietta, and Joe and John mines (Figs. 1 through 3). Several samples downstream from the mine impacted reach were collected in Prospect Gulch above its confluence with Cement Creek (PG1800 to PG2259 in Fig. 3), in order to better define the large gain in discharge in this lower reach. Other notable historical mines within the Prospect Gulch drainage basin include the Hercules mine and the Galena mine (located upstream from the detailed study reach). The mouth of Prospect Gulch is about $2.3 \mathrm{~km}$ downstream from the tracer injection site (PG-0).

\section{METHODS}

During low-flow conditions on September 29, 1999, a sodium-chloride tracer solution was injected into Prospect Gulch. Concurrent synoptic water-quality sampling determined loading of geochemical constituents throughout the study reach. Thirty-two water-quality samples were collected during the 14hour tracer injection, including 19 stream samples, 7 tributary inflows, 4 mine adits, and 2 spring systems. For quality-assurance, 3 sequential replicate samples and a de-ionized water field blank were collected. Objectives of this experiment were to use these chemical analyses to measure stream discharge, to calculate instream loads, and to identify inflows of chemical constituents under base-flow conditions.

\section{Tracer Injection}

Sodium chloride $(\mathrm{NaCl})$, was used as the tracer solution because little chloride is present in the surface waters of Prospect Gulch, salt is inexpensive and readily available, and it has little effect on the stream environment at low concentrations. The tracer solution was mixed with stream water to a concentration approaching saturation level the night before the injection. A saturated solution of $\mathrm{NaCl}$ was injected upstream from $\mathrm{PG}-0$ (Figs. 1 and 3) beginning at 9 PM on September 28, 1999. The injection apparatus included two high-capacity piston-core pumps driven by an electric motor that was battery powered. Tracer solution was pumped from a reservoir through plastic tubing to a pre-pump filter capsule and then through the pump to the stream. The pump was continuously monitored to maintain an injection rate of 1.9 liters per second (L/s). Samples of the injectate solution were analyzed gravimetrically to determine the salt concentration within 3 significant figures. An average chloride concentration of $137,000 \pm 500$ milligrams per liter $(\mathrm{mg} / \mathrm{L})$ was determined for 3 injectate samples collected at the beginning, middle, and end of the injection experiment.

The injection lasted 14 hours and was continuously monitored by collecting hourly stream samples at two automatic samplers located near the beginning and end of the reach. These samples were later analyzed for chloride to verify that the tracer concentrations in the stream were stable throughout the synoptic sampling. The injection pumps operated continuously throughout the 14-hour period and were shut off immediately after the last synoptic sample was collected. Hourly samples were collected at the downstream automatic sampler until the following day. 


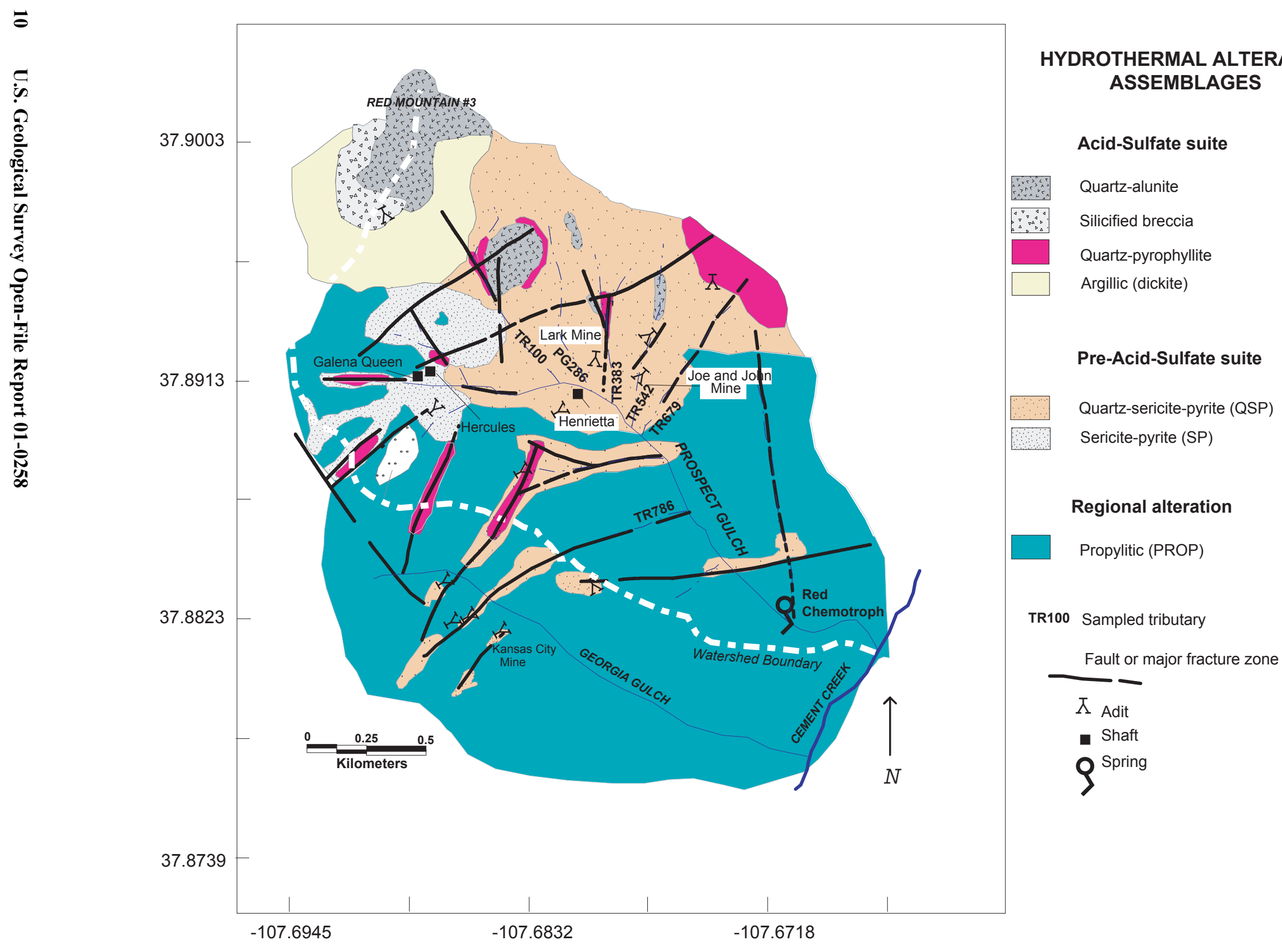

Figure 2. Hydrothermal alteration map showing distribution of acid-producing rock types. 


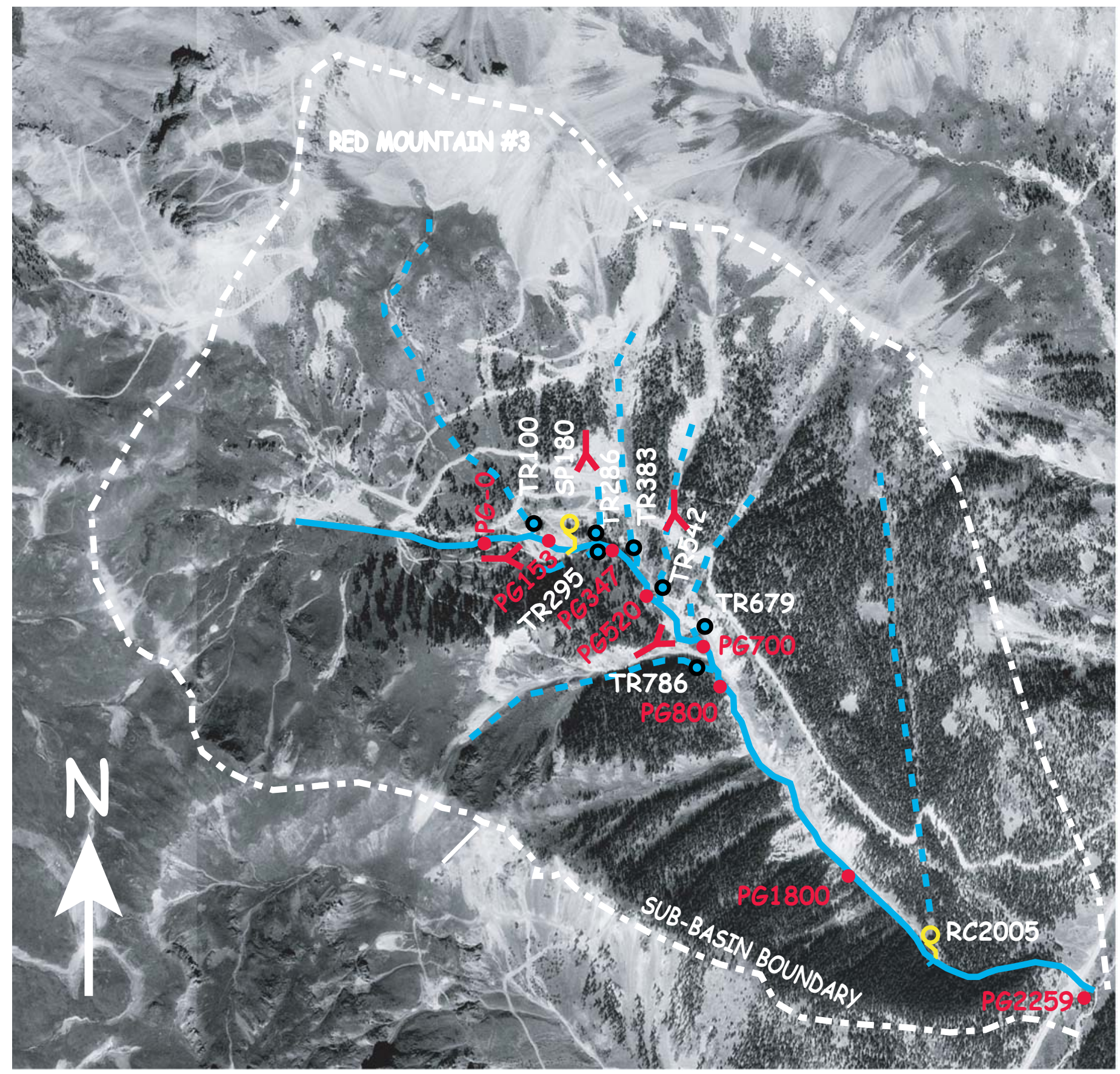

\section{EXPLANATION}
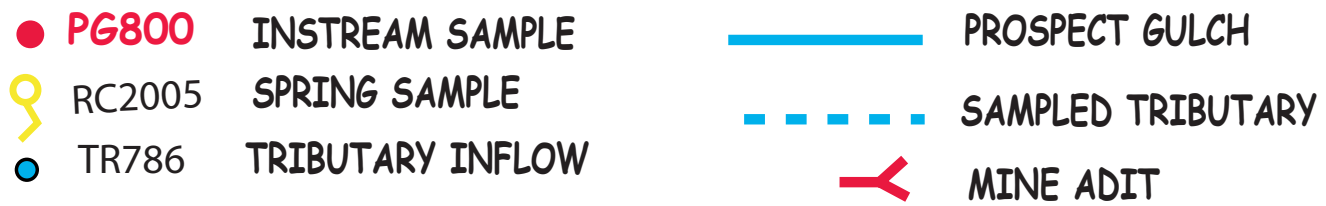

Figure 3. Aerial Photograph of Prospect Gulch showing water-quality sampling locations. 

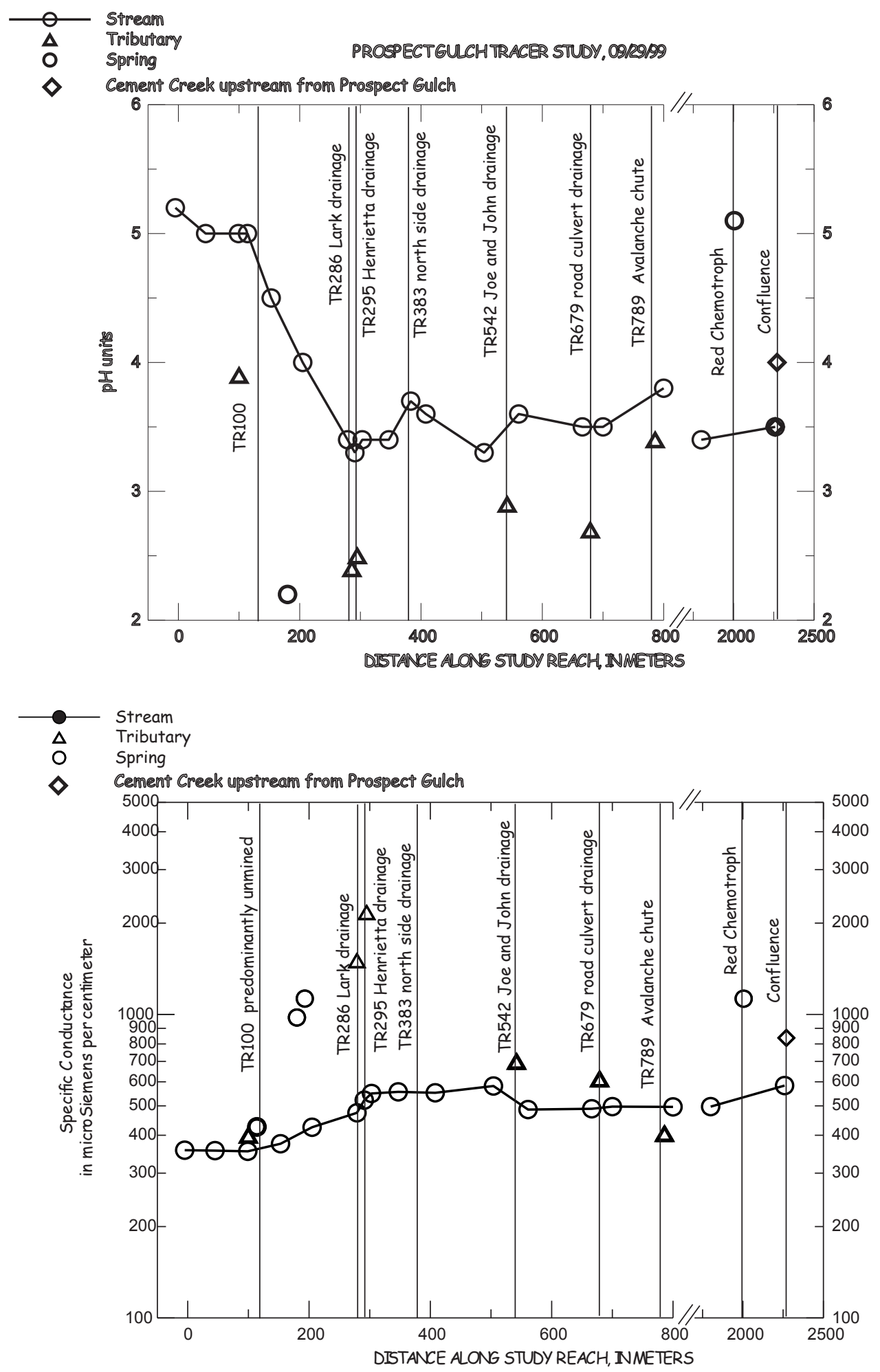

Figure 4. Longitudinal profile of $\mathrm{pH}$ and specific conductance with distance downstream. 


\section{Selection of Water-Quality Sampling Locations}

Field reconnaissance was conducted in order to select appropriate sampling sites of inflows including springs and tributaries; and corresponding stream transects above and below major inflows. Specific conductivity, $\mathrm{pH}$, bedrock exposures, and the presence of adits and waste dumps were used as guides when selecting samples sites in reaches where no tributaries were present. Station numbers were flagged according to the distance downstream from the injection site in meters; for example, PG700 is $700 \mathrm{~m}$ downstream from the injection site (PG-0; Figs. 1 and 3). All flowing springs and tributaries in the study reach were bracketed in order to obtain discharge values above and below the inflow. Subtraction of the calculated discharge for bracketed sites yields a discharge value for the corresponding tributary or spring. Field reconnaissance values for $\mathrm{pH}$ and specific conductance are shown in Fig. 4.

\section{Synoptic Sampling}

The synoptic sampling provided a detailed ì snapshotî of the solute concentration over the longitudinal profile of Prospect Gulch. Tributaries and spring inflows were collected concurrently with stream samples. Synoptic sampling occurred from 10:15 until 11:37 AM on September 29, 1999 and the pump was shut off at 11:40 AM. Chloride concentrations of samples collected at the two automatic samplers were stable during the synoptic sampling, verifying that steady-state conditions had been reached.

\section{Sampling and Analysis}

Samples were processed within 6 hours of collection at a field laboratory in Silverton, Colorado. Samples were filtered through $0.45-\mu \mathrm{m}$ membrane filters and acidified to a $\mathrm{pH}$ less than 2.0 for analysis of dissolved major and trace cations by inductively coupled plasma-atomic emission spectrometry (ICPAES) by a USGS laboratory in Denver, Colorado (Lamothe and others, 1996). Concentrations of chloride, sulfate, and other anions were determined by ion chromatography in filtered, unacidified samples. Only three of the samples at the beginning of the study reach had $\mathrm{pH}$ values greater than 4.5 and bicarbonate concentrations of approximately $1 \mathrm{mg} / \mathrm{L}$ were measured by fixed end-point titration. The rest of the samples had $\mathrm{pH}$ values less than 4.5 , hence the presence of bicarbonate as an anion was assumed to be negligible. Analytical detection limits reported by laboratories used in this study are in Table 1 (Lamothe and others, 1996; díAngelo and Ficklin, 1996). The concentrations of many trace elements including antimony, arsenic, beryllium, chromium, molybdenum, silver, and titanium were below the analytical detection limits of this technique for all of the samples analyzed.

\section{Quantification of Discharge}

Discharge was calculated at each water-sampling site in Prospect Gulch using the tracer-injection technique. This technique was chosen because of the difficulty and the error associated with traditional discharge-measurement techniques, such as current meters or flumes, when used in rocky steep-gradient channels (see Kimball, 1997). In addition, the tracer-injection approach provides an efficient means to obtain discharge and chemistry for a large number of samples collected during a brief timeframe. Traditional discharge measurements with a pygmy meter were made at the beginning and end of the study reach for comparison and calibration of the tracer results.

This technique is best described by the following equation:

$$
Q_{S}=\left(C_{I}^{*} Q_{I}\right) /\left(C_{D}-C_{U}\right)(1)
$$

where

$Q_{S}=$ stream discharge, in cubic ft per second;

$C_{I}=$ tracer concentration in the injection solution, in $\mathrm{mg} / \mathrm{L}$;

$Q_{I}=$ rate of injection to the stream, in cubic $\mathrm{ft}$ per second;

$C_{D}=$ tracer concentration downstream from injection site, in $\mathrm{mg} / \mathrm{L}$; and

$C_{U}=$ background concentration upstream from the injection site, in $\mathrm{mg} / \mathrm{L}$.

The discharge of bracketed inflows was determined by subtraction. Because the chloride concentrations of the inflows were different, the discharge estimates for the remaining synoptic sites are given by:

$$
Q_{S}=Q_{U}\left(C_{U} \tilde{n} C_{L}\right) /\left(C_{D} \tilde{n} C_{L}\right)
$$

where $C_{L}$ is tracer concentration in the inflow waters entering a given subreach, and $C_{U}$ and $Q_{U}$ represent the plateau tracer concentration and stream discharge for the synoptic site immediately upstream, and $C_{D}$ and $Q_{D}$ are the plateau tracer concentration and stream discharge for the synoptic site immediately downstream, respectively.

\section{Quantification of Loads}

Stream loading was evaluated using the approach of Kimball and others $(1998,2000)$ who have shown that calculating a cumulative sum of instream and inflow loads helps to evaluate whether the sampled inflow concentrations and loads are representative of the changes measured in the stream. For a more detailed discussion of quantification of loads, see Kimball and others $(1998,2000,2001)$.

Sampled instream load - the sampled instream load is determined by multiplying the filtered solute concentration by the discharge at each stream sampling site, and converting to the appropriate units. This technique provides a longitudinal profile 

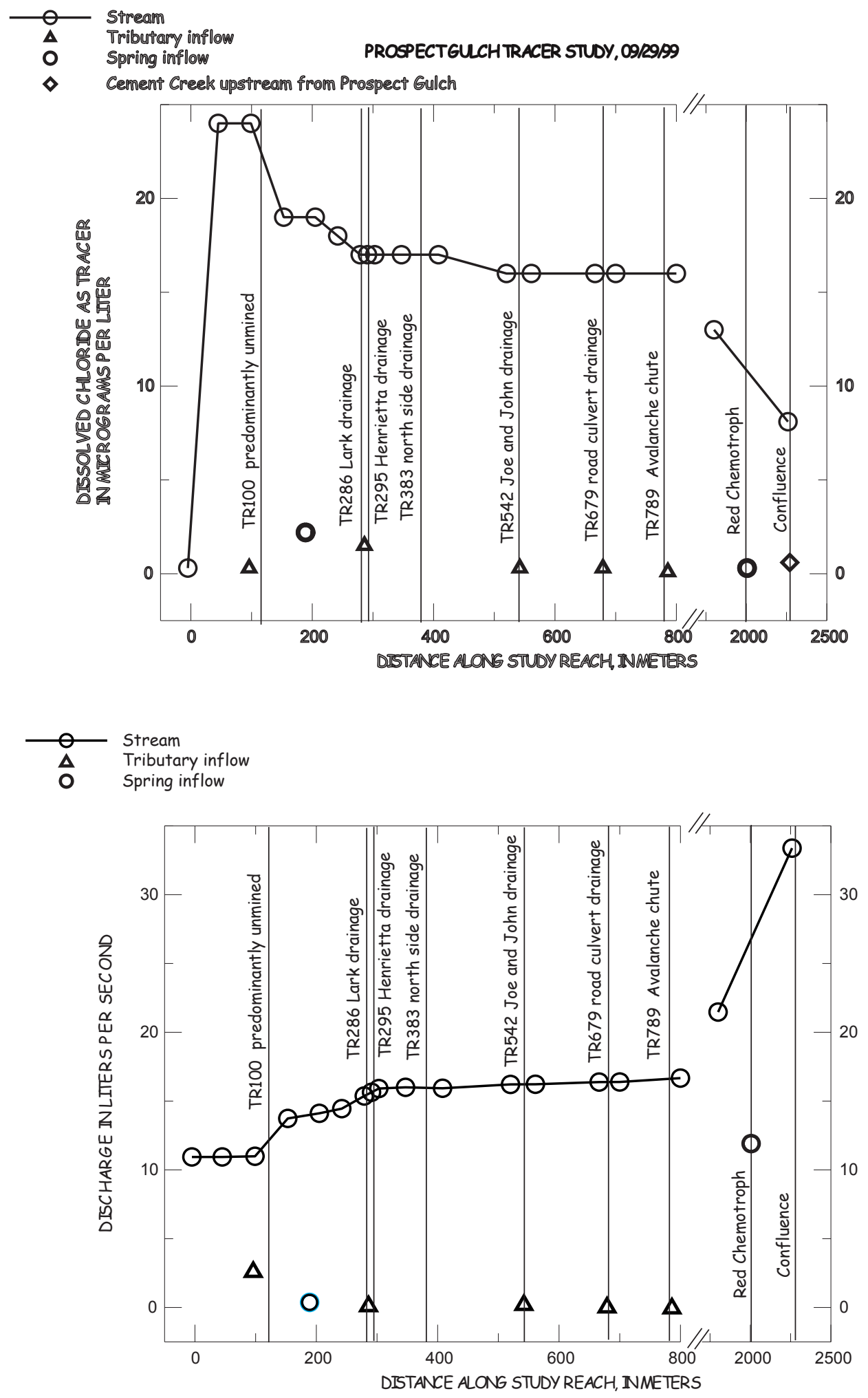

Figure 5. Longitudinal profile of chloride tracer and calculated discharge with distance downstream. 
Table 1. Analytical detection limits reported by laboratories used in the study.

\begin{tabular}{|c|c|c|c|c|}
\hline & \multirow[b]{2}{*}{ units } & \multicolumn{2}{|c|}{ Detection or Reporting Limits } & \multirow{2}{*}{$\begin{array}{c}\text { Below } \\
\text { Detection for } \\
\text { All Samples? }\end{array}$} \\
\hline & & $\begin{array}{c}\text { USGS } \\
\text { ICP-AES }^{1}\end{array}$ & $\begin{array}{l}\text { USGS } \\
I^{2}\end{array}$ & \\
\hline Major Cations & $\mathrm{mg} / \mathrm{L}$ & & & \\
\hline Calcium, Ca & $"$ & 0.1 & & \\
\hline Magnesium, Mg & $"$ & 0.1 & & \\
\hline Potassium, $\mathrm{K}$ & $"$ & 0.01 & & \\
\hline Sodium, $\mathrm{Na}$ & $"$ & 0.01 & & \\
\hline Silica, as Si & " & 0.1 & & \\
\hline Phosphorus, $\mathrm{P}$ & $"$ & 100 & & mostly \\
\hline Aluminum, Al & " & 0.01 & & \\
\hline Iron, Fe & $"$ & 0.02 & & \\
\hline Anions & $\mathrm{mg} / \mathrm{L}$ & & & \\
\hline Sulfate, $\mathrm{SO}_{4}$ & $"$ & & 1 & \\
\hline Chloride, $\mathrm{Cl}$ & $"$ & & 0.2 & \\
\hline Fluoride, F & $"$ & & 0.1 & \\
\hline Nitrate, $\mathrm{NO}_{3}$ & $"$ & & 0.1 & \\
\hline Trace Elements & $\mu \mathrm{g} / \mathrm{L}$ & & & \\
\hline Antimony, Sb & $"$ & 50 & & yes \\
\hline Arsenic, As & $"$ & 100 & & yes \\
\hline Barium, Ba & $"$ & 1 & & \\
\hline Boron, B & $"$ & 5 & & \\
\hline Cadmium, Cd & $"$ & 5 & & \\
\hline Chromium, $\mathrm{Cr}$ & $"$ & 10 & & yes \\
\hline Cobalt, Co & " & 10 & & \\
\hline Copper, Cu & $"$ & 10 & & \\
\hline Lead, Pb & $"$ & 50 & & \\
\hline Lithium, Li & $"$ & 10 & & \\
\hline Manganese, Mn & $"$ & 10 & & \\
\hline Molybdenum, Mo & $"$ & 20 & & yes \\
\hline Nickel, Ni & $"$ & 10 & & \\
\hline Silver, Ag & $"$ & 10 & & yes \\
\hline Strontium, Sr & $"$ & 1 & & \\
\hline Titanium, $\mathrm{Ti}$ & $"$ & 50 & & yes \\
\hline Vanadium, V & " & 10 & & mostly \\
\hline Zinc, Zn & $"$ & 10 & & \\
\hline
\end{tabular}




\begin{tabular}{|c|c|c|c|c|c|c|c|c|c|c|c|c|c|}
\hline Site & SAMPLE ID & Distance & FlowType & $\mathrm{pH}$ & SC & Tritium & $\mathrm{Cl}$ & $\mathbf{Q}$ & $\mathrm{Ca}$ & $\mathrm{Mg}$ & $\mathrm{Na}$ & SO4 & $\mathrm{Si}$ \\
\hline $5 \mathrm{~m}$ upstream from injection site & PG-5 & -5 & streamflow & 5.2 & 357 & $10.1 \pm 0.5$ & 0.39 & 11.0 & 45 & 5.4 & 0.96 & 130 & 3 \\
\hline $45 \mathrm{~m}$ downstream from injection site & PG45 & 45 & streamflow & 5.0 & 356 & NA & 24 & 11.0 & 43 & 5.1 & 18 & 130 & 3 \\
\hline $99 \mathrm{~m}$ downstream from injection site & PG99 & 99 & streamflow & 5.0 & 354 & NA & 24 & 11.0 & 42 & 4.9 & 17 & 130 & 3 \\
\hline North side tributary draining predominantly unmined area & TR100 & 100 & tributary & 3.9 & 400 & NA & 0.29 & 2.9 & 26 & 6.9 & 0.39 & 150 & 5.1 \\
\hline $153 \mathrm{~m}$ downstream from injection site & PG153 & 153 & streamflow & 4.5 & 375 & NA & 19 & 13.9 & 41 & 5.6 & 14 & 130 & 3.3 \\
\hline Small seep, north side & SP180 & 180 & spring & 2.9 & 977 & $9.0 \pm 0.5$ & 2.3 & 0.0 & 31 & 6.5 & 2 & 250 & 7.6 \\
\hline $205 \mathrm{~m}$ downstream from injection site & PG205 & 205 & streamflow & 4.0 & 425 & NA & 19 & 13.9 & 41 & 5.5 & 13 & 140 & 3.5 \\
\hline $242 \mathrm{~m}$ downstream from injection site & PG242 & 242 & streamflow & NA & NA & NA & 18 & 14.7 & 39 & 5.4 & 12 & 140 & 3.6 \\
\hline 279 m downstream from injection site & PG279 & 279 & streamflow & 3.4 & 474 & NA & 17 & 15.6 & 40 & 5.8 & 13 & 140 & 3.7 \\
\hline North side tributary draining Lark \#3 mine area & TR286 & 286 & tributary & 2.4 & 1506 & NA & 1.5 & 0.0 & 5 & 2.8 & 0.77 & 220 & 11 \\
\hline 291 m downstream from injection site & PG291 & 291 & streamflow & 3.3 & 522 & NA & 17 & 15.6 & 39 & 5.6 & 12 & 150 & 3.8 \\
\hline South side tributary draining Henrietta \#7 \& 8 mine area & TR295 & 295 & tributary & 2.5 & 2170 & $8.5 \pm 0.5$ & 0.5 & 0.0 & 34 & 12 & 1.4 & 740 & 20 \\
\hline $303 \mathrm{~m}$ downstream from injection site & PG303 & 303 & streamflow & 3.4 & 549 & NA & 17 & 15.6 & 39 & 5.5 & 12 & 160 & 4.1 \\
\hline $347 \mathrm{~m}$ downstream from injection site & PG347 & 347 & streamflow & 3.4 & 556 & NA & 17 & 15.6 & 39 & 5.6 & 11 & 160 & 4.2 \\
\hline Large gulch draining south slope of Red Mountain \#3 & TR383 & 383 & tributary & 3.7 & 237 & NA & 0.86 & 0.0 & 3.2 & 1.1 & 0.61 & 38 & 7.6 \\
\hline $408 \mathrm{~m}$ downstream from injection site & PG408 & 408 & streamflow & 3.6 & 552 & NA & 17 & 15.6 & 40 & 5.7 & 12 & 160 & 4.2 \\
\hline $520 \mathrm{~m}$ downstream from injection site & PG520 & 520 & streamflow & 3.3 & 481 & NA & 16 & 16.6 & 40 & 5.6 & 11 & 160 & 4.2 \\
\hline North side tributary draining Joe and John waste dump & TR542 & 542 & tributary & 2.9 & 700 & $9.0 \pm 0.4$ & 0.29 & 0.0 & 3.6 & 2.4 & 0.64 & 110 & 10 \\
\hline $561 \mathrm{~m}$ downstream from injection site & PG561 & 561 & streamflow & 3.6 & 486 & NA & 16 & 16.6 & 41 & 5.8 & 12 & 160 & 4.5 \\
\hline $666 \mathrm{~m}$ downstream from injection site & PG666 & 666 & streamflow & 3.5 & 489 & NA & 16 & 16.6 & 42 & 5.9 & 12 & 160 & 4.5 \\
\hline North side trib. draining J\&J mine and road culverts & TR679 & 679 & tributary & 2.7 & 613 & $11.6 \pm 0.5$ & 0.29 & 0.0 & 4.5 & 1.4 & 0.49 & 140 & 17 \\
\hline 700 m downstream from injection site & PG700 & 700 & streamflow & 3.5 & 497 & $9.7 \pm 0.4$ & 16 & 16.6 & 40 & 5.6 & 12 & 160 & 4.8 \\
\hline South side avalanche chute; mostly unmined drainage & TR786 & 786 & tributary & 3.4 & 405 & $8.4 \pm 0.5$ & 0.15 & 0.0 & 7.5 & 1.8 & 0.94 & 69 & 5.4 \\
\hline $800 \mathrm{~m}$ downstream from injection site & PG800 & 800 & streamflow & 3.8 & 496 & NA & 16 & 16.6 & 39 & 5.7 & 12 & 150 & 5 \\
\hline$m$ downstream from injection site & PG1800 & 1800 & streamflow & 3.4 & 497 & NA & 13 & 20.6 & 34 & 5.3 & 8.6 & 150 & 5.8 \\
\hline Red Chemotroph iron bog & RC2005 & 2005 & spring & 5.1 & 1127 & $5.7 \pm 0.5$ & 0.32 & 13.0 & 33 & 7.9 & 1.2 & 300 & 23 \\
\hline 2259 m downstream from injection site & PG2259 & 2259 & streamflow & 3.5 & 583 & NA & 8.1 & 33.5 & 34 & 6.5 & 6.2 & 200 & 13 \\
\hline Cement Creek upstream from Prospect Gulch & CCabvPG & NA & streamflow & 4.0 & 837 & NA & 0.65 & NA & 170 & 7.7 & 3.1 & 410 & 11 \\
\hline \multicolumn{14}{|l|}{ Abandoned mine discharge in study reach } \\
\hline Lark \#3 Mine adit & L3T & NA & adit & 4.1 & 228 & $9.6+0.5$ & 0.41 & NA & 16 & 0.9 & 2.6 & 83 & 8.1 \\
\hline Lark \#3 Mine drainage pipe & L3P & NA & adit & 4.0 & 157 & & 0.61 & NA & 16 & 1.7 & 3 & 53 & 11 \\
\hline Joe and John Mine drainage pipe & JJP & NA & adit & 2.7 & 1010 & $16.0+0.6$ & 0.45 & NA & 2.7 & 1.6 & 0.39 & 290 & 26 \\
\hline Henrietta \#7 Mine adit & $\mathrm{H} 7 \mathrm{~A}$ & NA & adit & 2.5 & 2450 & $11.7+0.5$ & 0.73 & NA & 49 & 7.5 & 0.83 & 1100 & 6.7 \\
\hline
\end{tabular}


Table 3. Dissolved concentrations and cumulative instream loads of selected metals and sulfate, Prospect Gulch, Colorado, September 1999.

[L/s, liters per second; mg/L, milligrams per liter; kg/day, kilograms per day; ug/L, micrograms per liter; SO4, sulfate; Al, aluminum; Fe, iron; Cu, copper; Zn, zinc;

\begin{tabular}{|c|c|c|c|c|c|c|c|c|c|c|c|c|c|c|c|c|c|c|c|c|c|}
\hline SAMPLE ID & $\begin{array}{l}\text { Distance } \\
\text { meters }\end{array}$ & FlowType & $\begin{array}{c}Q \mathbf{Q} \\
\mathrm{L} / \mathrm{s}\end{array}$ & $\begin{array}{c}\mathrm{SO}_{4} \\
\mathrm{mg} / \mathrm{L}\end{array}$ & $\begin{array}{c}\mathrm{SO}_{4} \\
\mathrm{~kg} / \text { day }\end{array}$ & $\begin{array}{c}\mathrm{Al} \\
\mathrm{mg} / \mathrm{L}\end{array}$ & $\begin{array}{c}\mathrm{Al} \\
\mathrm{kg} / \mathrm{day}\end{array}$ & $\begin{array}{c}\mathrm{Fe} \\
\mathrm{mg} / \mathrm{L}\end{array}$ & $\begin{array}{c}\mathrm{Fe} \\
\mathrm{kg} / \mathrm{day}\end{array}$ & $\begin{array}{c}\mathrm{Cu} \\
\mu \mathrm{g} / \mathrm{L}\end{array}$ & $\begin{array}{c}\text { Cu } \\
\text { kg/day }\end{array}$ & $\begin{array}{c}\mathrm{Zn} \\
\mu \mathrm{g} / \mathrm{L}\end{array}$ & $\begin{array}{c}\mathrm{Zn} \\
\mathrm{kg} / \mathrm{day}\end{array}$ & $\begin{array}{c}\text { Cd } \\
\mu \mathrm{g} / \mathrm{L}\end{array}$ & $\begin{array}{c}\text { Co } \\
\mu \mathrm{g} / \mathrm{L}\end{array}$ & $\begin{array}{c}\mathrm{Li} \\
\mu \mathrm{g} / \mathrm{L}\end{array}$ & $\begin{array}{c}\text { Mn } \\
\mu \mathrm{g} / \mathrm{L}\end{array}$ & $\begin{array}{c}\mathrm{Ni} \\
\mu \mathrm{g} / \mathrm{L}\end{array}$ & $\begin{array}{c}\mathrm{Pb} \\
\mu \mathrm{g} / \mathrm{L}\end{array}$ & $\begin{array}{c}\mathrm{Sr} \\
\mu \mathrm{g} / \mathrm{L}\end{array}$ & $\begin{array}{l}\text { Sum of } \\
\text { Metals }\end{array}$ \\
\hline PG-5 & -5 & streamflow & 11.0 & 130 & 123 & 0.73 & 0.69 & 0.27 & 0.26 & 86 & 0.08 & 850 & 0.80 & $<5$ & $<10$ & $<10$ & 290 & $<10$ & $<50$ & 1100 & 936 \\
\hline PG45 & 45 & streamflow & 11.0 & 130 & 123 & 0.75 & 0.71 & 0.29 & 0.27 & 83 & 0.08 & 810 & 0.77 & $<5$ & $<10$ & $<10$ & 290 & $<10$ & $<50$ & 1100 & 893 \\
\hline TR100 & 100 & tributary & 2.9 & 150 & 36 & 9.6 & 2.29 & 0.55 & 0.13 & 18 & 0.00 & 150 & 0.04 & $<5$ & 24 & $<10$ & 1000 & 18 & 50 & 240 & 260 \\
\hline PG153 & 153 & streamflow & 13.9 & 130 & 154 & 2.4 & 2.85 & 0.36 & 0.43 & 79 & 0.09 & 730 & 0.87 & $<5$ & $<10$ & $<10$ & 420 & 10 & 50 & 990 & 869 \\
\hline SP180 & 180 & spring & 0.0 & 250 & 8 & 10 & 0.32 & 20 & 0.63 & 590 & 0.02 & 3300 & 0.10 & 14 & 29 & $<10$ & 800 & 23 & $<50$ & 610 & 3,956 \\
\hline PG205 & 205 & streamflow & 13.9 & 140 & 171 & 2.8 & 3.41 & 0.84 & 1.02 & 130 & 0.16 & 890 & 1.09 & $<5$ & $<10$ & $<10$ & 440 & 11 & 58 & 940 & 1,089 \\
\hline PG279 & 279 & streamflow & 15.6 & 140 & 186 & 3.3 & 4.38 & 2.2 & 2.92 & 180 & 0.24 & 1000 & 1.33 & $<5$ & 11 & $<10$ & 460 & 11 & 54 & 980 & 1,256 \\
\hline TR286 & 286 & tributary & 0.0 & 220 & 5 & 6.5 & 0.15 & 38 & 0.88 & 1100 & 0.03 & 6300 & 0.15 & 28 & 32 & 10 & 300 & 25 & 81 & 42 & 7,576 \\
\hline PG291 & 291 & streamflow & 15.6 & 150 & 202 & 3.3 & 4.45 & 3.6 & 4.85 & 210 & 0.28 & 1200 & 1.62 & 5.6 & $<10$ & $<10$ & 450 & 11 & 59 & 930 & 1,486 \\
\hline TR295 & 295 & tributary & 0.0 & 740 & 0 & 20 & 0.00 & 140 & 0.00 & 4500 & 0.00 & 8400 & 0.00 & 35 & 89 & 38 & 1900 & 56 & $<50$ & 280 & 13,080 \\
\hline PG303 & 303 & streamflow & 15.6 & 160 & 216 & 3.4 & 4.58 & 5 & 6.74 & 260 & 0.35 & 1300 & 1.75 & 6 & 10 & $<10$ & 460 & 14 & 60 & 910 & 1,650 \\
\hline PG347 & 347 & streamflow & 15.6 & 160 & 216 & 3.5 & 4.72 & 5 & 6.74 & 270 & 0.36 & 1400 & 1.89 & 6.2 & 12 & $<10$ & 460 & 12 & 58 & 910 & 1,758 \\
\hline TR383 & 383 & tributary & 0.0 & 38 & 0 & 1.9 & 0.00 & 0.4 & 0.00 & 250 & 0.00 & 1500 & 0.00 & 6.9 & 10 & $<10$ & 110 & $<10$ & $<50$ & 23 & 1,767 \\
\hline PG408 & 408 & streamflow & 15.6 & 160 & 216 & 3.4 & 4.58 & 4.9 & 6.60 & 260 & 0.35 & 1400 & 1.89 & 6.2 & 10 & $<10$ & 460 & 12 & 54 & 950 & 1,742 \\
\hline PG520 & 520 & streamflow & 16.6 & 160 & 229 & 3.3 & 4.73 & 4.8 & 6.88 & 260 & 0.37 & 1400 & 2.01 & 5.6 & 12 & $<10$ & 440 & 12 & 52 & 940 & 1,742 \\
\hline PG561 & 561 & streamflow & 16.6 & 160 & 229 & 3.5 & 5.01 & 5.1 & 7.30 & 300 & 0.43 & 1500 & 2.15 & 6.6 & 11 & $<10$ & 470 & 11 & 62 & 980 & 1,891 \\
\hline PG666 & 666 & streamflow & 16.6 & 160 & 229 & 3.6 & 5.16 & 5 & 7.17 & 300 & 0.43 & 1500 & 2.15 & 6.8 & 13 & $<10$ & 480 & 12 & 54 & 990 & 1,886 \\
\hline TR679 & 679 & tributary & 0.0 & 140 & 0 & 9.3 & 0.00 & 16 & 0.00 & 410 & 0.00 & 5800 & 0.00 & 28 & 23 & $<10$ & 160 & 17 & 490 & 45 & 6,768 \\
\hline PG700 & 700 & streamflow & 16.6 & 160 & 229 & 3.8 & 5.44 & 5.3 & 7.58 & 300 & 0.43 & 1600 & 2.29 & 7.1 & 12 & $<10$ & 460 & 12 & 63 & 920 & 1,994 \\
\hline TR786 & 786 & tributary & 0.0 & 69 & 0 & 3.1 & 0.00 & 2.1 & 0.00 & 700 & 0.00 & 260 & 0.00 & $<5$ & $<10$ & $<10$ & 280 & $<10$ & $<50$ & 62 & 960 \\
\hline PG800 & 800 & streamflow & 16.6 & 150 & 215 & 3.9 & 5.59 & 5.4 & 7.74 & 340 & 0.49 & 1700 & 2.44 & 7 & 11 & $<10$ & 480 & 13 & 66 & 900 & 2,137 \\
\hline PG1800 & 1800 & streamflow & 20.6 & 150 & 267 & 4.4 & 7.83 & 4.3 & 7.65 & 360 & 0.64 & 1700 & 3.03 & 7.9 & 12 & $<10$ & 500 & 13 & 71 & 720 & 2,164 \\
\hline RC2005 & 2005 & spring & 13.0 & 300 & 337 & 21 & 23.59 & 29 & 32.57 & $<10$ & ND & 1000 & 1.12 & $<5$ & 42 & 12 & 700 & 32 & $<50$ & 410 & 1,074 \\
\hline PG2259 & 2259 & streamflow & 33.5 & 200 & 579 & 10 & 28.94 & 20 & 57.89 & 230 & 0.67 & 1500 & 4.34 & 6.3 & 24 & $<10$ & 610 & 18 & $<50$ & 640 & 1,778 \\
\hline CCabvPG & NA & streamflow & ND & 410 & ND & 5 & ND & 6.4 & ND & 460 & ND & 3600 & ND & 42 & 14 & 19 & 2600 & 12 & $<50$ & 1600 & 4,128 \\
\hline \multicolumn{22}{|c|}{ Abandoned mine discharge in study reach } \\
\hline L3T & NA & adit & ND & 83 & ND & 0.35 & ND & 24 & ND & 160 & ND & 2200 & ND & 9.2 & 10 & 270 & 220 & 11 & $<50$ & 130 & 2,390 \\
\hline L3P & NA & adit & ND & 53 & ND & 1.1 & ND & 0.12 & ND & 230 & ND & 3100 & ND & 12 & $<10$ & $<10$ & 190 & $<10$ & 97 & 140 & 3,439 \\
\hline JJP & NA & adit & ND & 290 & ND & 13 & ND & 62 & ND & 640 & ND & 11000 & ND & 54 & 39 & $<10$ & 190 & 28 & 1400 & 47 & 13,161 \\
\hline $\mathrm{H} 7 \mathrm{~A}$ & NA & adit & ND & 1100 & ND & 23 & ND & 270 & ND & 590 & ND & 8200 & ND & 35 & 170 & 17 & 910 & 110 & $<50$ & 270 & 9,105 \\
\hline
\end{tabular}


of stream chemistry and which is used to identify the relative contribution and location of different metal sources in the watershed.

Cumulative instream load-The net change of instream load between two stream sites is given by subtracting the upstream load from the downstream load. In cases where the difference is significantly negative (allowing for analytical uncertainty), metal precipitation or sorption may be removing metals from solution. The sum of all positive gains between sites is called the cumulative instream load. Comparison of the cumulative instream load to the sampled instream load indicates the extent of metal attenuation along the stream reach, if any.

Cumulative inflow load-Another way to consider the change in load between sites is to multiply the dissolved concentration of the sampled inflow by the positive change in discharge between the upstream and downstream sites. The sum of these sampled inflow loads is called the cumulative inflow load. If the cumulative inflow load is less than the cumulative instream load, it is likely there has been inflow of unsampled water with higher concentrations than that sampled. If, conversely, the cumulative inflow load is greater than the cumulative instream load, it is likely there has been inflow of unsampled water with lower concentrations, or else there has been a loss of metal from the stream through attenuation.

\section{RESULTS AND DISCUSSION}

Chemical results were divided into two tables. Site descriptions, source, distance, discharge, $\mathrm{pH}$, specific conductance, and concentrations of the tracer and selected major ions are listed in Table 2. Dissolved concentrations and loads for aluminum, copper, iron, zinc, and sulfate are listed in Table 3. In addition, measured concentrations for several selected trace elements (cadmium, cobalt, lithium, nickel, lead, and strontium) are also included in Table 3. Quality assurance procedures for chemical analyses are as described in Wirt and others (1999).

\section{Discharge}

During the morning of the synoptic sampling, ice was melting along the edges of the stream as air temperatures warmed. Most of the ice had melted by the time sampling began. The water samples needed to be collected quickly because there was concern that uneven melting of the ice might dilute the chemistry of the samples to varying degrees. Water temperatures for all the stream samples ranged from about 2.5 to $3.3 \int \mathrm{C}$. Little if any dilution apparently occurred, however, as was later indicated by the chloride profile for the stream (Fig. 5). The chloride profile shows little evidence of diurnal variations, as would be expected during steady-state conditions.

Dilution of chloride tracer was used to calculate discharge values (Tables 2 and 3). Background concentrations of chloride in Prospect Gulch were very low $(\leq 0.4 \mathrm{mg} / \mathrm{L})$ compared with the injected concentrations ( 8.0 to $24 \mathrm{mg} / \mathrm{L}$ ). Although one seep near the abandoned mine sites contained as much as $2.3 \mathrm{mg} / \mathrm{L}$ of chloride (SP180), several of these small sampled seeps that were treated as potential inflows did not measurably increase the discharge of the stream, therefore the seeps apparently did not contribute a significant new source of chloride to the stream. The systematic decrease of chloride concentration along the study reach was assumed to be entirely from dilution by inflows having little if any chloride, and is shown as a longitudinal profile in Fig. 5.

Table 4 summarizes the discharge loads in selected stream reaches for comparison of particular source areas. The $800-\mathrm{m}$ detailed study reach (PG-0 to PG-800) contributed 17 percent of the discharge at the mouth of Prospect Gulch. One might expect this percentage to be higher, given that there are 7 well-defined topographic drainages that contribute to the 800-m long reach (see Figs. 3 and 6). In contrast, there are only two well-defined drainage tributaries in the 1,460 meters between the lower end of the detailed study reach and the confluence of Prospect Gulch and Cement Creek (PG800 to PG2259). Yet that (albeit longer) reach contributed half of the discharge at the mouth of Prospect Gulch. At the time of the study, however, only one of the 7 tributaries in the detailed study reach was flowing (TR100). The $800-\mathrm{m}$ study reach is in a section of the sub-basin where the slopes of the narrow valley are generally less steep. Downstream from PG800, the mountain slopes rise more steeply from the bed of the stream and the canyon cross section is narrower. Despite variations in topography and the number of tributary drainages, the base level or slope of the stream channel is fairly constant from PG-0 to the mouth (PG2259), as shown in Fig. $6 \mathrm{~B}$, although the valley cross-section is considerably narrower between PG800 and PG1800.

Prospect Gulch gained 5.6 L/s over the detailed 800-m study reach. This compares with a discharge of $11.0 \mathrm{~L} / \mathrm{s}$ at the start of the study reach and a discharge of $33.5 \mathrm{~L} / \mathrm{s}$ at the mouth of Prospect Gulch. Thus, 83 percent of the total discharge was generated upstream and downstream of the detailed study reach. The single largest increase in discharge, a gain of $12.9 \mathrm{~L} / \mathrm{s}$, is associated with ground-water inflow in the stream segment near a large, iron spring known as the ì Red Chemotrophî (site RC2005; Fig. 6). Combined with the gain from unsampled ground-water inflows in the stream segment immediately upstream (PG800 to PG1800), discharge in the lower half of Prospect Gulch increases by $16.9 \mathrm{~L} / \mathrm{s}$. On the basis of visual inspection, the gain begins to occur just upstream from PG1800, where the channel widens and becomes braided. Whether the inflow near PG1800 can be assigned to the ground-water system feeding the iron spring is undetermined because there were not enough samples in this reach. Some of the gain could occur along another large fracture system between PG800 and PG1800 (see Fig. 2), or the gain could be from diffuse inflow associated with a topographic change in the valley cross-section profile.

Within the detailed 800-m study reach, two inflows accounted for 82 percent of the increase in flow. The first inflow (TR100) was a small stream that enters Prospect Gulch 
from the north bank one hundred meters downstream from PG-0. This tributary contributed up to $2.9 \mathrm{~L} / \mathrm{s}$ (about 52 percent of the increase in flow) from a drainage area that is thought to be largely unaffected by past mining activities. The TR100 drainage contains old mine roads, and several drill pad sites, but no mine adits or waste dumps. The flowing stream can be traced to fairly high elevations on the southern slope of Red Mountain \#3. The upper slopes of Red Mountain \#3 consist of red and bleached tan bedrock, caused by the oxidation of large quantities of finely-disseminated pyrite. The pre-acid-sulfate mineral assemblages exposed in the upper slopes of Red Mountain \#3ó which include the headwaters of tributary drainage TR-100ó produce some of the most acidic surface waters in the Cement Creek watershed (Fig. 2; Bove and others, 1999). The production of the acid water occurs by natural weathering of the pyrite, and is largely not exacerbated by mining activity in this area. In addition, several large fractures or faults intersect the tributary drainage and probably feed ground water to TR-100.

The second notable contribution of about $1.7 \mathrm{~L} / \mathrm{s}$ (about 30 percent of the increase in flow in the detailed study area) was from ground-water inflow that occurred in a short reach between PG205 and PG279. Most of the gain appeared to occur as inflow through the streambed. Several explanations for the ground-water inflow in this reach are possible. First, the source of the ground water may be snowmelt or surface runoff that has percolated beneath the mine-waste dumps on both sides of the channel, as evidenced by a series of small seeps along north bank (for example, site SP180). Another possibility is that the small seeps are part of the same ground-water system as another group of seeps that are located upgradient from the waste dump to the north of the stream. These upslope seeps occur along the two roadcuts that link the Lark and the Henrietta mine sites. It is quite likely that this spring network was much larger and was partially buried by the waste dump. A third possibility is that exposed bedrock in the stream channel at $230 \mathrm{~m}$ downstream from PG-0 could force ground water that is moving through shallow alluvium and wasterock materials to discharge into the stream. A combination of any of these scenarios is also likely.

Yet another explanation for the source of the ground water between PG153 and PG279 is that, in 1977, the Henrietta \#8 (or 800 level) mine tunnel was drilled at stream level in this reach (Steve Fearn, oral communication, 2001). This tunnel was connected with the Henrietta \#7 and \#10 levels, but has since collapsed and is buried with waste material. Hence, ground water contributing to this reach could be draining through mine tunnels intersecting water-bearing fractures. Inflow in this reach now emanates from areas that have been greatly disturbed by past mining activities. Herron and others (1998) surveyed the Henrietta waste dump on both sides of Prospect Gulch and estimated its volume at 23,000 $\mathrm{m}^{3}$. Waste-rock materials are highly pyritic, and include small areas of base-metal ores and possibly some silver ores that were never removed from the site (Herron and others, 1998).

Although the stream segment between PG279 and PG520 contains three drainages with small seeps at their outlets (TR286, TR295, and TR383), these tributaries were not visibly flowing and calculated discharge did not increase in Prospect Gulch. An 18percent gain of $1.0 \mathrm{~L} / \mathrm{s}$, however, occurred between PG408 and PG520ó a stream segment incised into partially exposed bedrock with no major tributaries. No further increases in streamflow were measured from PG520 to PG800. This is somewhat surprising in that this $300-\mathrm{m}$ stream segment also contains three drainages (TR542, TR679, and TR786) that had small seeps near their outlets. Each of these three seeps at the mouths of drainage tributaries have been observed to have a small trickle of flowing water during the month of September in both 1998 and 2000, and produce larger surface-water inflows at other times of the year, particularly during peak snow-melt season. The lack of base flow discharge from surface drainages in this segment is evidence that base flow is derived almost entirely from deeper ground-water movement in bedrock (as opposed to shallow ground water from unconsolidated rock and sediment) by late summer and early fall. These observations lead us to speculate as to whether colluvial fans and talus slopes in the upper Prospect Gulch sub-basin are large enough to generate sustained ground-water discharge to springs and streams throughout the summer and fall.

Thus all of the relatively small gains in flow in the detailed study reach were contributed from just three sourcesó more than half coming from TR100, and the remainder as ground-water inflow between PG205 and PG279 and between PG408 and PG520. Perennial tributary TR100 is clearly associated with mapped fracture zones and exposed bedrock is present in both of the two other gaining reaches. These observations indicate that during the low-flow conditions of late summer, streamflow in Prospect Gulch is largelyó if not entirelyó derived from deeper circulating ground water moving along bedrock fractures or bedrock surfaces.

\section{Field Reconnaissance Chemistry}

The principal changes in stream chemistry in the detailed study reach can be summarized by the major changes in $\mathrm{pH}$ and specific conductance (Fig. 4). These field parameters were measured during reconnaissance on the day previous to the tracer injection. Upstream from the study area, the $\mathrm{pH}$ was 5.2 and specific conductance in micro-Siemens per centimeter was relatively low (357 microSiemens per centimeter; $\mu \mathrm{S} / \mathrm{cm}$ ). Within the first 300 meters, stream $\mathrm{pH}$ decreased sharply to 3.4 and specific conductance increased to $556 \mu \mathrm{S} / \mathrm{cm}$ because of (1) acidic inflows from tributary TR100 and (2) ground-water seepage through the streambed near the Lark-Henrietta waste dumps. Inflow from TR100 had a relatively low $\mathrm{pH}$ value (3.9) compared with that of the main stream ( site PG99; $\mathrm{pH}=5.0$ ) and a somewhat higher specific conductance $(400 \mu \mathrm{S} / \mathrm{cm})$ versus $354 \mu \mathrm{S} / \mathrm{cm}$ for Prospect Gulch (PG99). Some of the lowest $\mathrm{pH}$ values in the study (ranging from 2.4 to 2.9) were measured from several disconnected seeps along the channel at sites SP180, TR286, and TR295. These sites had among the highest specific conductance values measured in the study, ranging from 977 to $2,170 \mu \mathrm{S} / \mathrm{cm}$. These values compare with a $\mathrm{pH}$ of 2.5 and a specific conductance of $2,450 \mu \mathrm{S} / \mathrm{cm}$ for the 
Table 4. Summary of changes in discharge and cumulative instream loads by percent of reach and percent of sub-basin.

\begin{tabular}{|c|c|c|c|c|c|c|c|c|}
\hline $\begin{array}{c}\text { Stream } \\
\text { Segment }\end{array}$ & $\begin{array}{c}\text { Discharge } \\
\text { L/s }\end{array}$ & $\begin{array}{c}\text { change in } \\
\text { discharge } \\
\text { L/s } \\
\end{array}$ & $\begin{array}{c}\text { \% change in } \\
\text { discharge } \\
\text { for reach }\end{array}$ & $\begin{array}{c}\text { of discharge } \\
\text { n Prospec } \\
\text { Gulch } \\
\end{array}$ & $\begin{array}{c}\mathrm{SO}_{4} \\
\mathrm{~kg} / \text { day }\end{array}$ & $\begin{array}{c}\text { change in } \mathrm{SO}_{4} \\
\text { load } \\
\mathrm{kg} / \text { day }\end{array}$ & $\begin{array}{c}\% \text { change in } \\
\mathrm{SO}_{4} \text { load } \\
\text { for reach }\end{array}$ & $\begin{array}{c}\% \text { of } \mathrm{SO}_{4} \\
\text { in Prospect } \\
\text { Gulch } \\
\end{array}$ \\
\hline stream from $\mathrm{P}$ & 11.0 & - & - & 33 & 123 & - & - & 21 \\
\hline PG-5 to PG15 & 13.9 & 2.9 & 26.4 & 9 & 154 & 31.4 & 25.6 & 5 \\
\hline G153 to PG2 & 15.6 & 1.7 & 12.2 & 5 & 186 & 31.5 & 20.4 & 5 \\
\hline G279 to PG52 & 16.6 & 1.0 & 6.4 & 3 & 229 & 43.6 & 23.5 & 8 \\
\hline G520 to PG8 & 16.6 & 0.0 & 0.0 & 0 & 215 & -14.3 & -6.3 & -2 \\
\hline G800 to PG18 & 20.6 & 4.0 & 24.1 & 12 & 267 & 51.8 & 24.1 & 9 \\
\hline G1800 to PG22 & 33.5 & 12.9 & 63 & 39 & 579 & 311.9 & 117 & 54 \\
\hline spect Gulch T & 33.5 & & & 100 & & & & 100 \\
\hline $\begin{array}{c}\text { Stream } \\
\text { Segment }\end{array}$ & $\begin{array}{c}\text { Al } \\
\mathrm{kg} / \text { day }\end{array}$ & $\begin{array}{c}\text { change in } Q \\
\text { load } \\
\text { kg/day } \\
\end{array}$ & $\begin{array}{c}\% \text { change in } \\
\text { Al load } \\
\text { for reach }\end{array}$ & $\begin{array}{c}\% \text { of Al } \\
\text { n Prospec } \\
\text { Gulch } \\
\end{array}$ & $\begin{array}{c}\mathrm{Fe} \\
\mathrm{kg} / \text { day }\end{array}$ & $\begin{array}{c}\text { change in Fe } \\
\text { load } \\
\text { kg/day } \\
\end{array}$ & $\begin{array}{c}\% \text { change in } \\
\text { Fe load } \\
\text { for reach }\end{array}$ & $\begin{array}{c}\% \text { of Fe } \\
\text { in Prospect } \\
\text { Gulch } \\
\end{array}$ \\
\hline stream from $\mathrm{P}$ & 0.69 & - & - & 2 & 0.26 & - & - & 0 \\
\hline PG-5 to PG15 & 2.85 & 2.2 & 313 & 7 & 0.43 & 0.2 & 67 & 0 \\
\hline G153 to PG2 & 4.38 & 1.5 & 54 & 5 & 2.92 & 2.5 & 583 & 4 \\
\hline G279 to PG52 & 4.73 & 0.4 & 8.0 & 1 & 6.88 & 4.0 & 136 & 7 \\
\hline G520 to PG8 & 5.59 & 0.9 & 18.2 & 3 & 7.74 & 0.9 & 12.5 & 1 \\
\hline G800 to PG18 & 7.83 & 2.2 & 40.0 & 8 & 7.65 & -0.1 & -1.2 & 0 \\
\hline G1800 to $P G 22$ & 28.94 & 21.1 & 270 & 73 & 57.89 & 50.2 & 656 & 87 \\
\hline \multicolumn{2}{|l|}{ spect Gulch Total } & & & 100 & & & & 100 \\
\hline $\begin{array}{c}\text { Stream } \\
\text { Segment }\end{array}$ & $\begin{array}{c}\text { Cu } \\
\mathrm{kg} / \text { day }\end{array}$ & $\begin{array}{c}\text { change in } \mathrm{Cu} \\
\text { load } \\
\text { kg/day } \\
\end{array}$ & $\begin{array}{c}\% \text { change in } \\
\text { Cu load } \\
\text { for reach }\end{array}$ & $\begin{array}{c}\text { \% of } \mathrm{Cu} \\
\text { n Prospec } \\
\text { Gulch } \\
\end{array}$ & $\begin{array}{c}\mathrm{Zn} \\
\text { kg/day }\end{array}$ & $\begin{array}{c}\text { change in Zn } \\
\text { load } \\
\text { kg/day }\end{array}$ & $\begin{array}{c}\% \text { change in } \\
\mathrm{Zn} \text { load } \\
\text { for reach }\end{array}$ & $\begin{array}{c}\text { \% of } \mathrm{Zn} \\
\text { in Prospect } \\
\text { Gulch }\end{array}$ \\
\hline stream from $P$ & 0.08 & $\overline{-}$ & $\overline{-}$ & 12 & 0.80 & - & - & 19 \\
\hline PG-5 to PG15 & 0.09 & 0.01 & 15.4 & 2 & 0.87 & 0.06 & 7.9 & 1 \\
\hline G153 to PG2 & 0.24 & 0.15 & 155 & 22 & 1.33 & 0.46 & 53 & 11 \\
\hline G279 to PG52 & 0.37 & 0.13 & 56 & 20 & 2.01 & 0.68 & 51 & 16 \\
\hline G520 to PG8 & 0.49 & 0.11 & 30.8 & 17 & 2.44 & 0.43 & 21.4 & 10 \\
\hline G800 to PG18 & 0.64 & 0.15 & 31.4 & 23 & 3.03 & 0.59 & 24.1 & 14 \\
\hline G1800 to PG22 & 0.67 & 0.02 & 3.9 & 4 & 4.34 & 1.32 & 43.5 & 30 \\
\hline spect Gulch Tot & & & & 100 & & & & 100 \\
\hline
\end{tabular}


Henrietta \#7 mine adit (site H7A) and a pH of 2.7 and 1,010 $\mu \mathrm{S} /$ $\mathrm{cm}$ for a sample collected from a drainage pipe from the Joe and Johns mine (site JJP). The drainage from the Lark \#3 tunnel (site L3T) had been rerouted to a French drain as part of a remediation effort a few weeks earlier, and at the time of the tracer study had a $\mathrm{pH}$ of 4.1 and a specific conductance of $228 \mu \mathrm{S} / \mathrm{cm}$.

Between PG347 and the confluence, the stream pH fluctuates slightly, apparently in response to small inflows, but does not deviate substantially from a $\mathrm{pH}$ of 3.5. Likewise, specific conductance also fluctuates and increases slightly from 556 to $583 \mu \mathrm{S} / \mathrm{cm}$ above the confluence, an increase comparable to the measurement error for the meter of \pm 5 percent. Notable smallscale variations in $\mathrm{pH}$ and specific conductance occur downstream from small seeps near tributary drainages. Except for the Red Chemotroph and TR100 (which will be considered in the next section), none of the topographical tributary drainages contributed a measurable increase in discharge to Prospect Gulch.

Between PG347 and PG800, there were four tributary drainages with specific conductance ranging from 237 to 700 $\mu \mathrm{S} / \mathrm{cm}$ and $\mathrm{pH}$ values ranging from 2.7 to 3.7 ; however there was little effect on $\mathrm{pH}$ and specific conductance of the stream. Two of these tributaries (TR383 and TR786) have mining activity upgradient from the sampling sites but were indirectly impacted by mining to a lesser degree. Tributary TR383 drains a large area on the north slope of Red Mountain \# 3 between the Lark \#3 and the Joe and John mines. Analytical results for site TR383 in Table 3 has substantially elevated concentrations above background sites for dissolved copper $(250 \mu \mathrm{g} / \mathrm{L})$, zinc $(1,500 \mu \mathrm{g} / \mathrm{L})$, and cadmium $(6.9 \mu \mathrm{g} / \mathrm{L})$, respectively, and relatively large sum of metals value of $1,767 \mu \mathrm{g} / \mathrm{L}$. Tributary TR786 is an avalanche chute on the south side of the watershed that drains the Henrietta levels \#1, \#2, and \#3 at high elevation, with an elevated dissolved copper concentration of $700 \mu \mathrm{g} / \mathrm{L}$ (Table 3). Although these two tributaries have similar $\mathrm{pH}$ values, their specific conductance values $(23.7$ and $400 \mu \mathrm{S} / \mathrm{cm})$ are relatively dilute in comparison to those of nearby adits and their tributaries in this reach of Prospect Gulch. In contrast, the other two tributaries (TR542 and TR679) are both substantially more acidic and have higher specific conductance than the stream (Table 2). The sum of metals value for both of these mine-impacted sites exceeds $6,000 \mu \mathrm{g} / \mathrm{L}$. Both these tributaries appear to receive drainage from the Joe and John mine adit and from its waste dump. TR679 also receives road ditch drainage bearing storm runoff from other areas that were disturbed by mining. Although these two tributaries have relatively poor water quality, their inflow contribution at the time of the study was negligible. Thus, over this entire stream segment (PG347 to PG800), $\mathrm{pH}$ was virtually unchanged, and specific conductance decreased slightly from 556 to $496 \mu \mathrm{S} / \mathrm{cm}$ (Fig. 4B).

In the two lower stream segments downstream from the detailed study reach and upstream from the mouth of Prospect Gulch, changes in $\mathrm{pH}$ and specific conductance were not detailed enough to fully describe the large changes in stream chemistry that occurred. Although $\mathrm{pH}$ did not change substantially with the large inflow in the vicinity of the Red
Chemotroph iron spring, specific conductance increased substantially from 497 to $583 \mu \mathrm{S} / \mathrm{cm}$ between PG1800 and PG2259. The specific conductance of the Red Chemotroph near its outlet was measured at $1,127 \mu \mathrm{S} / \mathrm{cm}$. Using a mass balance approach, the specific conductance of the composite inflow to the stream segment should be about $670 \mu \mathrm{S} / \mathrm{cm}$. Thus, not all of the water associated with the Red Chemotroph spring network had a specific conductance as high as that of the inflow that was measured. Some of the unsampled inflow is probably relatively dilute inflow near PG1800.

It should be noted that the $\mathrm{pH}$ value of 5.1 for the Red Chemotroph was measured near the outlet where the discharge was dripping over the steep bank and was probably in equilibrium with atmospheric oxygen. On September 4, 2000, a sample collected from the deepest portion of the spring had a $\mathrm{pH}$ value of 2.9 and a dissolved oxygen value of $1.1 \mathrm{mg} / \mathrm{L}$. Groundwater quality from the iron spring system is spatially variable and changes substantially as the water comes in contact with atmosphere and precipitates iron sulfate minerals. In addition, the small decline in stream gradient as Prospect Gulch approaches Cement Creek (Fig. 6B) probably causes relatively shallow ground-water flow that may be unrelated to Red Chemotroph discharge to the stream in this lower reach. Thus, the $\mathrm{pH}$ and specific conductance values for the Red Chemotroph iron spring are probably not representative of the cumulative inflow from all of the sources in this reach. Another possible factor for changes in water quality is that the stream may be in contact with less altered bedrock (as indicated the distribution of rock types in Fig. 2) providing some degree of acid neutralization potential.

\section{Ground-water Age and Fracture Controls on Hydrology}

Tritium has a half-life of 12.3 years and is produced naturally in the atmosphere, allowing it to be used as an age-dating technique for ground water. The most important source for modern studies, however, is atmospheric testing of thermonuclear weapons testing which occurred between 1952 and 1969 (Drever, 1982). Tritium values for streamflow samples derived predominantly from snowmelt in Prospect Gulch during high flow in June 1999 were on the order of 9.5 to 11.5 TU (L. Wirt, unpub. data). A tritium value of $5.7 \pm 0.5$ tritium units (TU) from the Red Chemotroph iron spring (Table 2) indicates one of two possible scenarios; (1) the ground-water age is approximately equivalent to radioactive decay of one half life (approximately one decade), or (2) that spring may is an ambiguous composite of modern and relatively older ground water (greater than one decade) that either predates or postdates atmospheric bomb testing. In either scenario, the lower tritium value indicates the ground water has undergone a slower, deeper travel path through bedrock, probably along the large fracture system discharging to the iron spring (Fig. 2). The surface expression of this fracture system is clearly visible as a steep linear drainage in Fig. 6. Bove and others (2000) have shown that the water chemistry of the Red Chemotroph spring is influenced by preacid-sulfate mineral assemblages that are exposed along the 


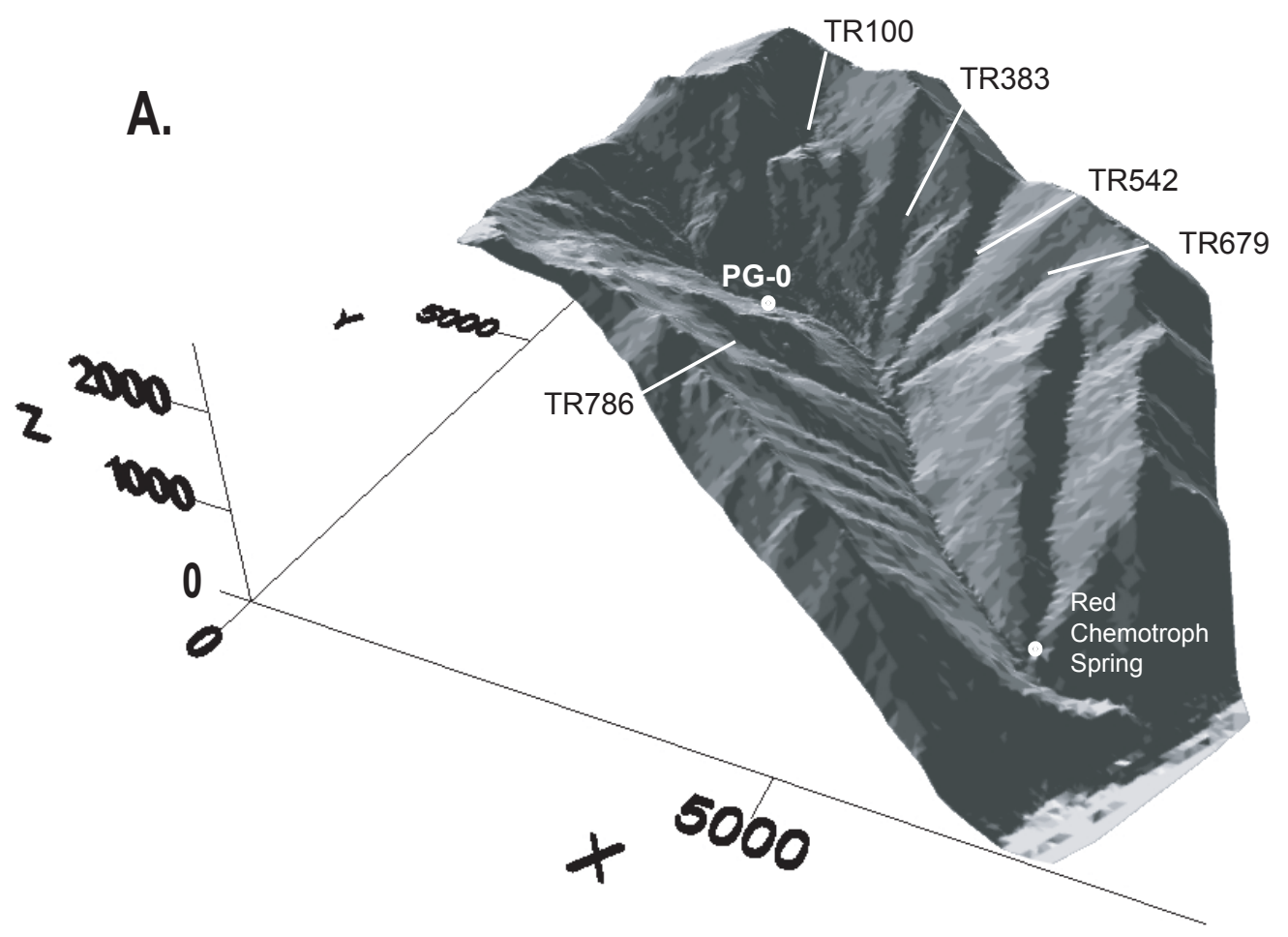

B.

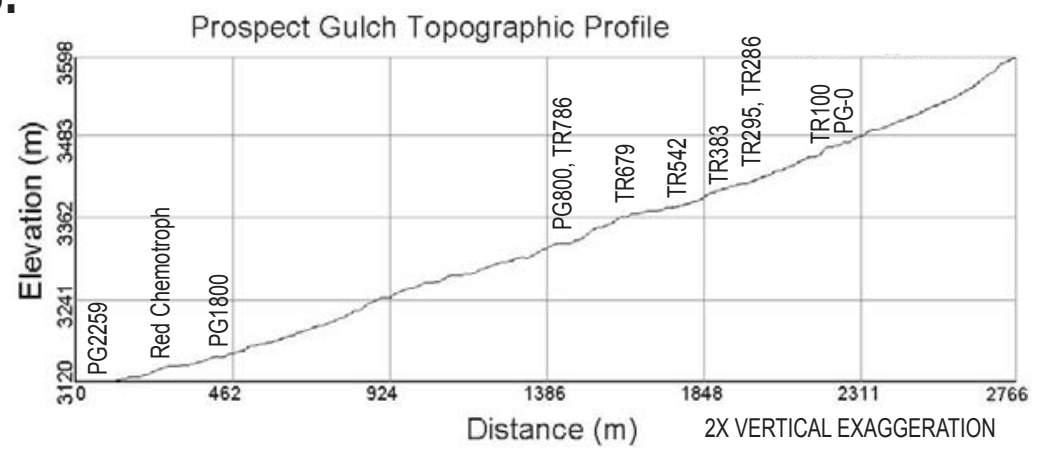

Figure 6. Three dimensional view of Prospect Gulch sub-basin and elevation of the stream profile..

upper slopes of Prospect Gulch, indicating that the fracture system may serve as a conduit for high-altitude drainage to the stream. Other iron springs in the Cement Creek watershed are in association with fracture networks. For example, the two iron springs that flank each side of Cement Creek between Fairview Gulch and Cascade Gulch are oriented along a fault (D. Yager, oral commun., 2000).

The tritium value for the sample collected from perennial tributary TR100 (Table 2) was $8.7 \mathrm{TU}$, indicating a relatively modern age within one or two years of the time of recharge. Tributary TR100 is another prominent drainage related to intersecting fracture networks (refer to Figs. 2 and 6) in the upper elevations of the sub-basin. These fractures are in contact with both pre-acid-sulfate alteration assemblages and pyrophyllitic alteration assemblages that contain a higher proportion of aluminum-silicate minerals.

For comparison, tritium values in Table 2 for samples from the Henrietta \#7, Lark \#3, and Joe and John adits were 11.7, 16, and 9.6 to TU, respectivelyó suggesting that the adit waters are modern in age. A modern age value indicates that the ground water has a ground-water residence time of a few years or less and is predominantly derived from annual snowmelt in high elevation areas. The slightly higher tritium value for the Lark \#3 adit water may indicate that predominantly modern ground 
water has mixed with a small fraction of bomb pulse water from the 1950ís and 1960ís.

\section{Metal Concentrations and Load Profiles by Reach}

Beginning of study reach to PG153-Metal concentrations were relatively low upstream from the 800-m study area (PG-5), but increased downstream from the first perennial tributary (TR100). Discharge over the reach increased by 26.4 percent, whereas sampled instream loads of sulfate, aluminum, iron, copper, and zinc increased over the reach by $25.6,313,67,15.4$, and 7.9, respectively (Table 4; Figs. 7 to 11 ). Whereas the increase in sulfate loads was proportionate to the increase in discharge, inflow from TR100 had a substantially higher aluminum concentration than that of Prospect Gulch $(9.6 \mathrm{mg} / \mathrm{L}$ versus $0.81 \mathrm{mg} /$ L; Table 3). Consequently, between PG-5 and PG153, sampled instream loads for aluminum increased from 0.69 to 2.85 kilograms per day (kg/day).

PG153 to PG279_-Discharge increased by 12.3 percent in the stream segment from PG153 to PG 279, which is characterized by acidic inflows near mine-waste dumps. The increase in discharge occurred from unsampled ground-water seepage in a 75-m reach between PG205 and PG279. Sampled instream loads increased 20.4 percent for sulfate, 54 percent for aluminum, 583 percent for iron, 155 percent for copper, and 53 percent for zinc. The large increase in iron loading coincides with the pronounced decrease in stream $\mathrm{pH}$ (Fig. 4A). Sampled instream loads for aluminum increased $1.53 \mathrm{~kg} /$ day, thus the aluminum load from ground-water seepage in this reach is equivalent to about 70 percent of the load contributed by tributary TR100.

PG279 to PG520_Although metal loading for this stream reach was not as great as the previous stream segments; loads continued to increase substantially (Table 4). The changes in sampled instream loads probably have little to do with increasing discharge, given the relatively small 6.4 percent increase in discharge that occurred entirely downstream from PG408. Sulfate loading increased at roughly the same rate as in the previous stream segment (23.5); however, the increase in aluminum loading decreased to 8.0 percent. Iron, copper, and zinc loads continued to increase substantially by 136,56 and 51 percent, respectively. Because metal concentrations, sulfate, $\mathrm{pH}$, and specific conductance values changed little downstream from PG303 (Table 3, Fig. 4), the large increases in iron, copper, and zinc loads in this reach are largely attributed to contact with the LarkHenrietta waste dumps and acidic seeps at the beginning of this reach. The chemistry of water leaving the mined areas is characterized by seeps near the confluence of the two small tributaries that drain the main Lark and Henrietta mine sites (TR286) and (TR295).

PG520 to PG800 — This reach drains the Joe and John mine (TR542 and TR679) and the Henrietta \#10 waste dump and was characterized by virtually no change in discharge (or $\mathrm{pH}$ and specific conductance values) and comparatively small changes in dissolved loads. Sulfate loads decreased by 6.3 percent, although aluminum, iron, and zinc loads increased by 12.5 to 21.4 percent (Table 4 ). The largest increase in loading of 30.8 percent was for copper. The avalanche chute at TR786 has a few mined prospects in its headwaters, but is appears relatively unimpacted by mining as evidenced by its low specific conductance (Fig. 4B) and, except for 700 microgram per liter $(\mu \mathrm{g} / \mathrm{L})$ of copper, low concentrations of metals (Table 3 ).

PG800 to PG1800 — Discharge, and loads for sulfate and zinc all increased by 24.1 percent over this stream segment. The aluminum and copper loads increased by 40.0 and 31.4 percent, respectively; whereas the iron load decreased slightly by 1.2 percent. As there were no significant tributaries or mine sites in this reach, changes in water quality are largely attributed to natural sources and processes. The density of sampling sites in this reach was insufficient to determine whether the major fracture upstream of PG1800 shown in Fig. 2 was water bearing. This reach of Prospect Gulch is predominantly in contact with less intensely altered propylitic rock (Fig. 2), compared with the acid-sulfate alteration assemblages in the upper sub-basin.

PG1800 to PG2259_-The largest changes in metal loading overwhelmingly occurred in this reach upstream from the mouth of Prospect Gulch (PG2259). From PG1800 to PG2259, discharge increased by 63 percent and sampled instream loads of sulfate, aluminum, and iron increased by 117, 270, and 656 percent, respectively (Table 4). Concentrations of sulfate increased from 150 to $200 \mathrm{mg} / \mathrm{L}$; aluminum concentrations increased from 4.4 to $10 \mathrm{mg} / \mathrm{L}$; and iron concentrations increased from 4.3 to $20 \mathrm{mg} / \mathrm{L}$ (Figs. 7-9; Table 3). The Red Chemotroph iron spring, the major sampled inflow, had no analytically detectable copper. Consequently, loading of copper remained essentially constant and concentrations decreased from 360 to $230 \mu \mathrm{g} / \mathrm{L}$ in this reach, largely attributed to dilution (Table 3; Fig. 10A). Concentrations of zinc decreased from 1,700 to $1,500 \mu \mathrm{g} / \mathrm{L}$, however, in this instance the Red Chemotroph sample contributed a large inflow with $1,000 \mu \mathrm{g} / \mathrm{L}$ of dissolved zinc. Hence the sampled instream load for zinc increased by 43.5 percent (Tables 3 and 4; Fig. 11B).

Natural attenuation-Comparison of the sampled instream load versus the cumulative instream load (Figs. 7B to 11B) was excellent, indicating that transport is conservative and that little natural attenuationó such as sorption or precipitationó is occurring along the length of Prospect Gulch. These two profiles will differ only if there are stream segments with a net loss of dissolved constituent. Because both sorption and precipitation are $\mathrm{pH}$ dependentó and because $\mathrm{pH}$ is low throughout most of Prospect Gulchó such losses of dissolvedconstituents are unlikely. The small negative loads of sulfate and iron in Table 4 are insignificant in that they account for less 

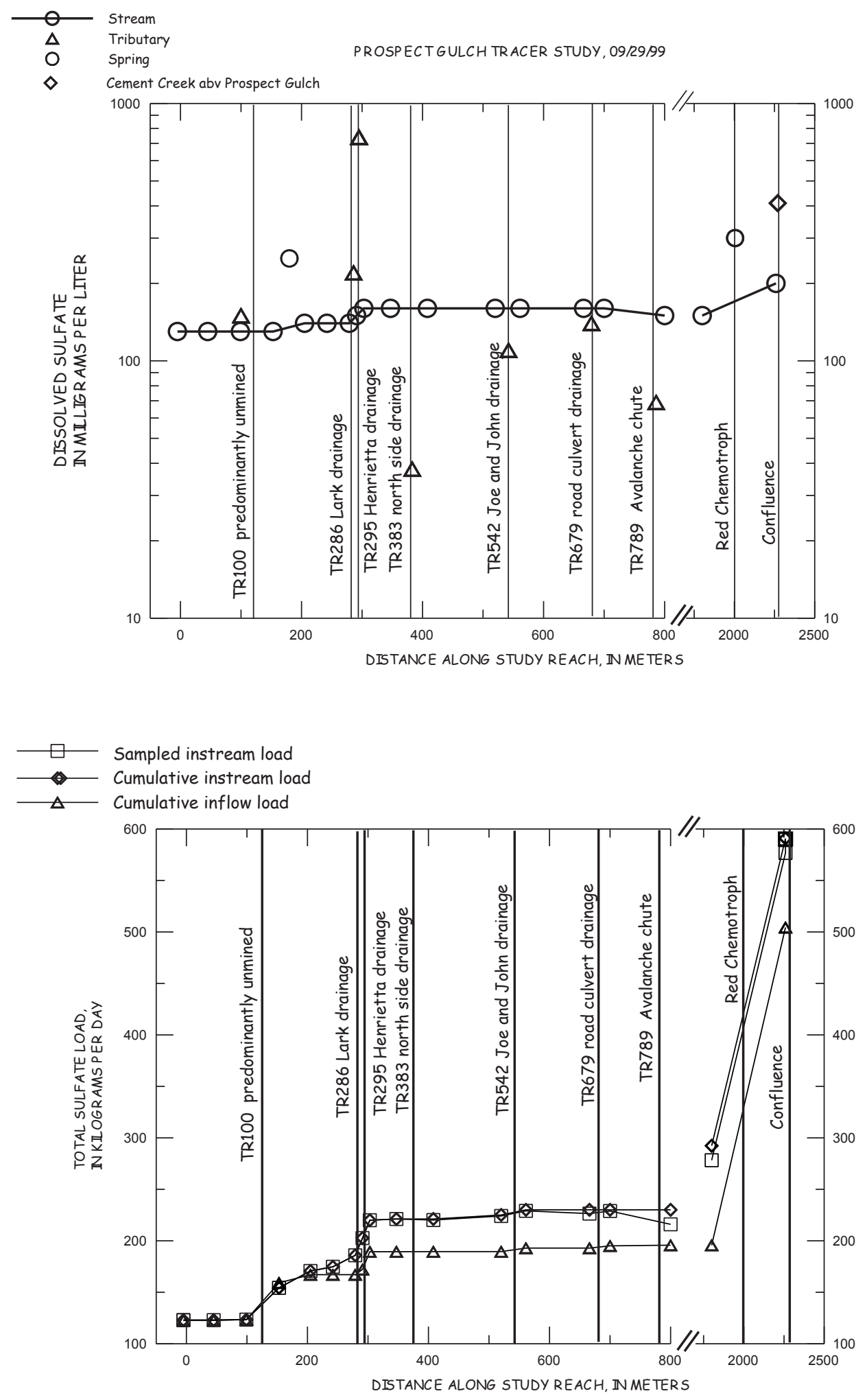

Figure 7. Concentration and load profile of sulfate with distance downstream. 

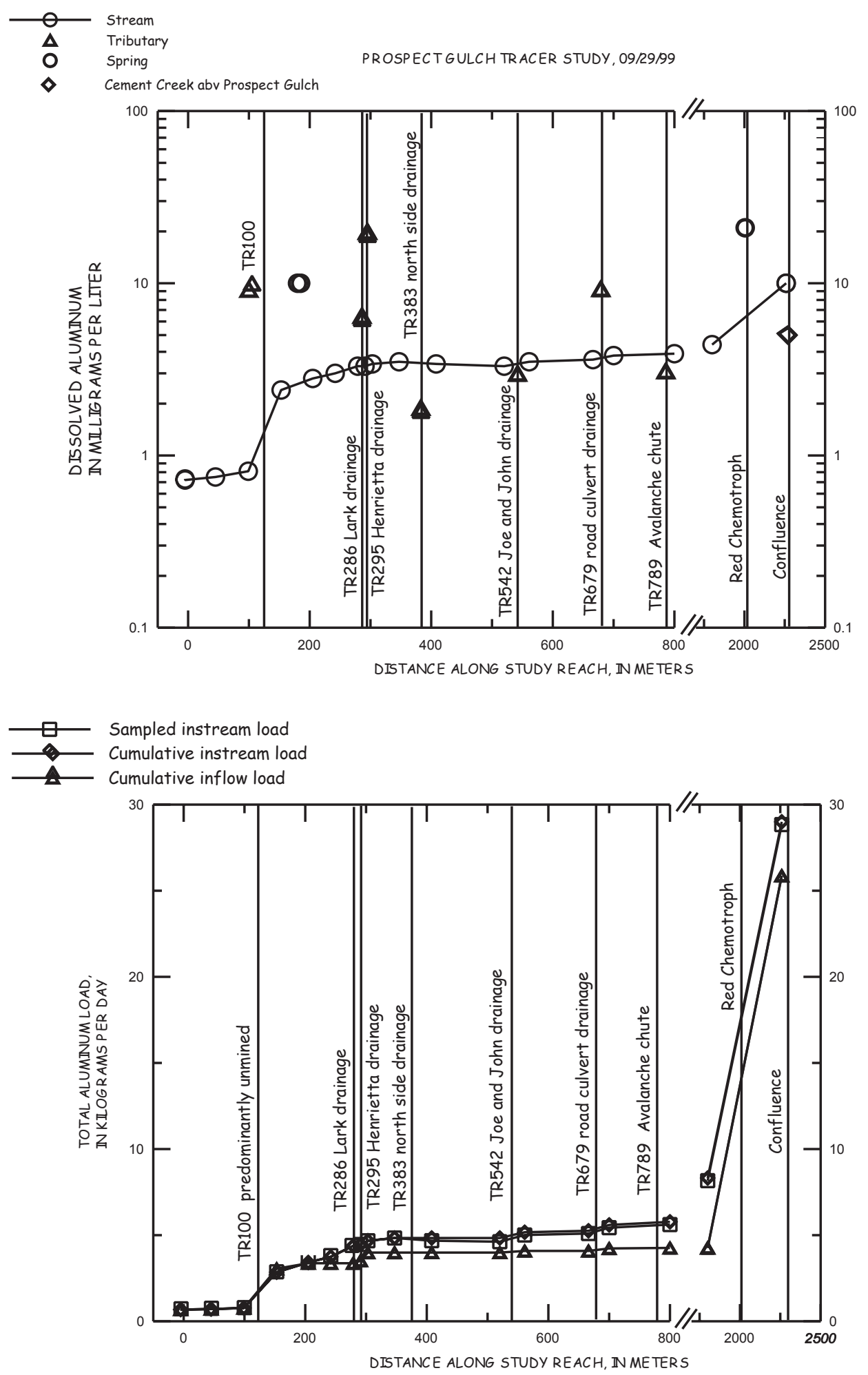

Figure 8. Concentration and load profile of aluminum with distance downstream. 

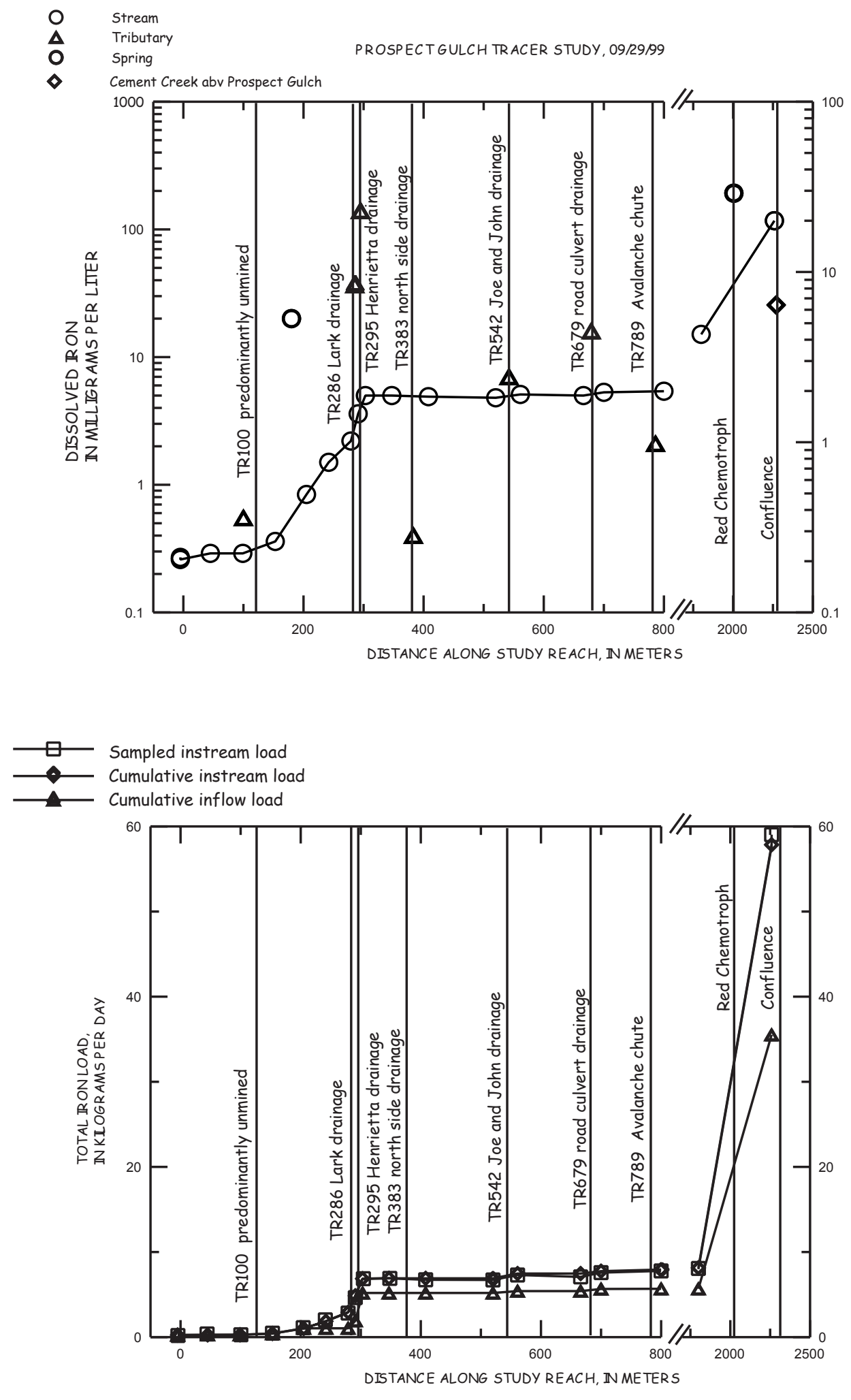

Figure 9. Concentration and load profile of iron with distance downstream. 

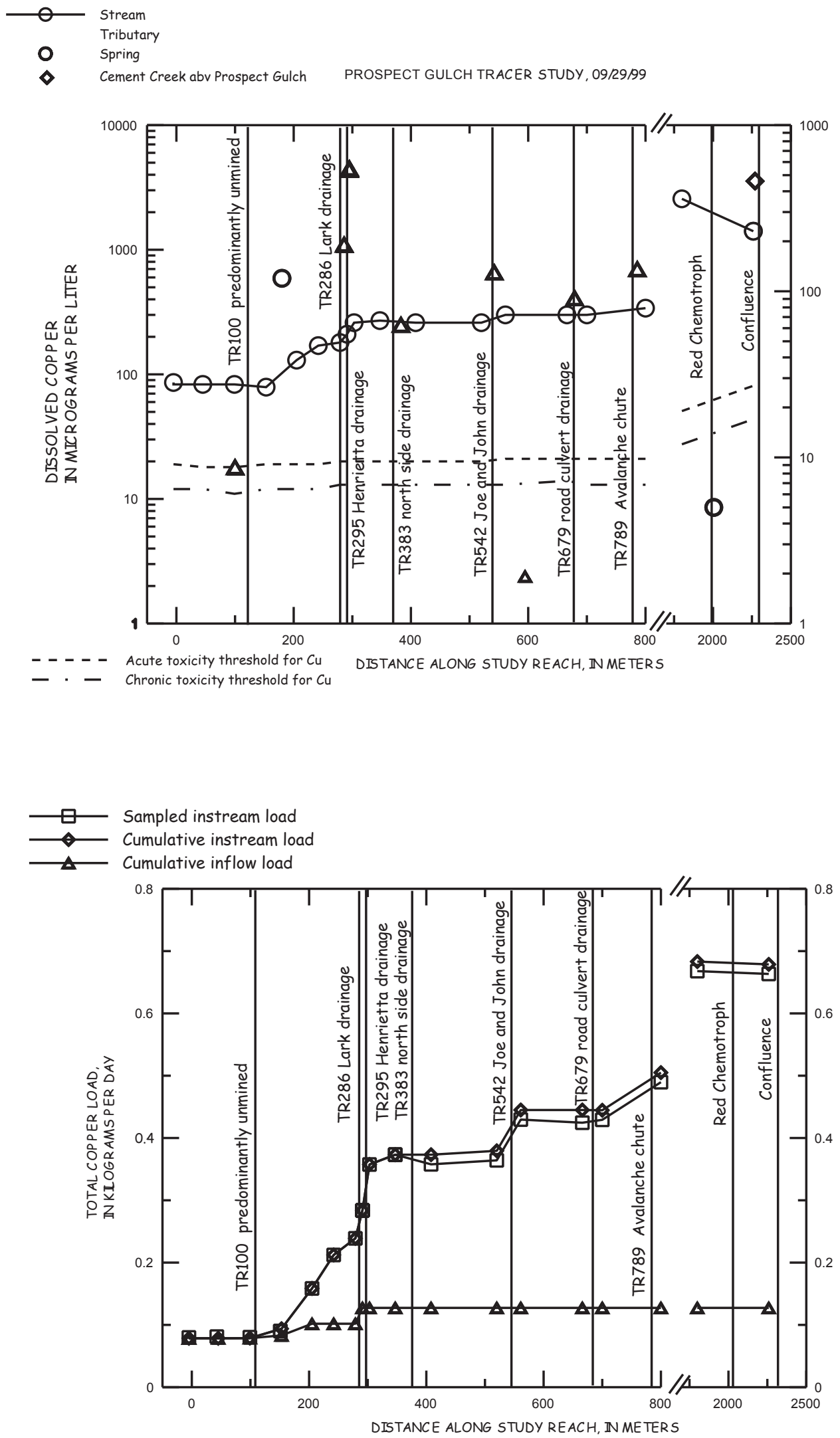

Figure 10. Concentration and load profile of copper with distance downstream. 

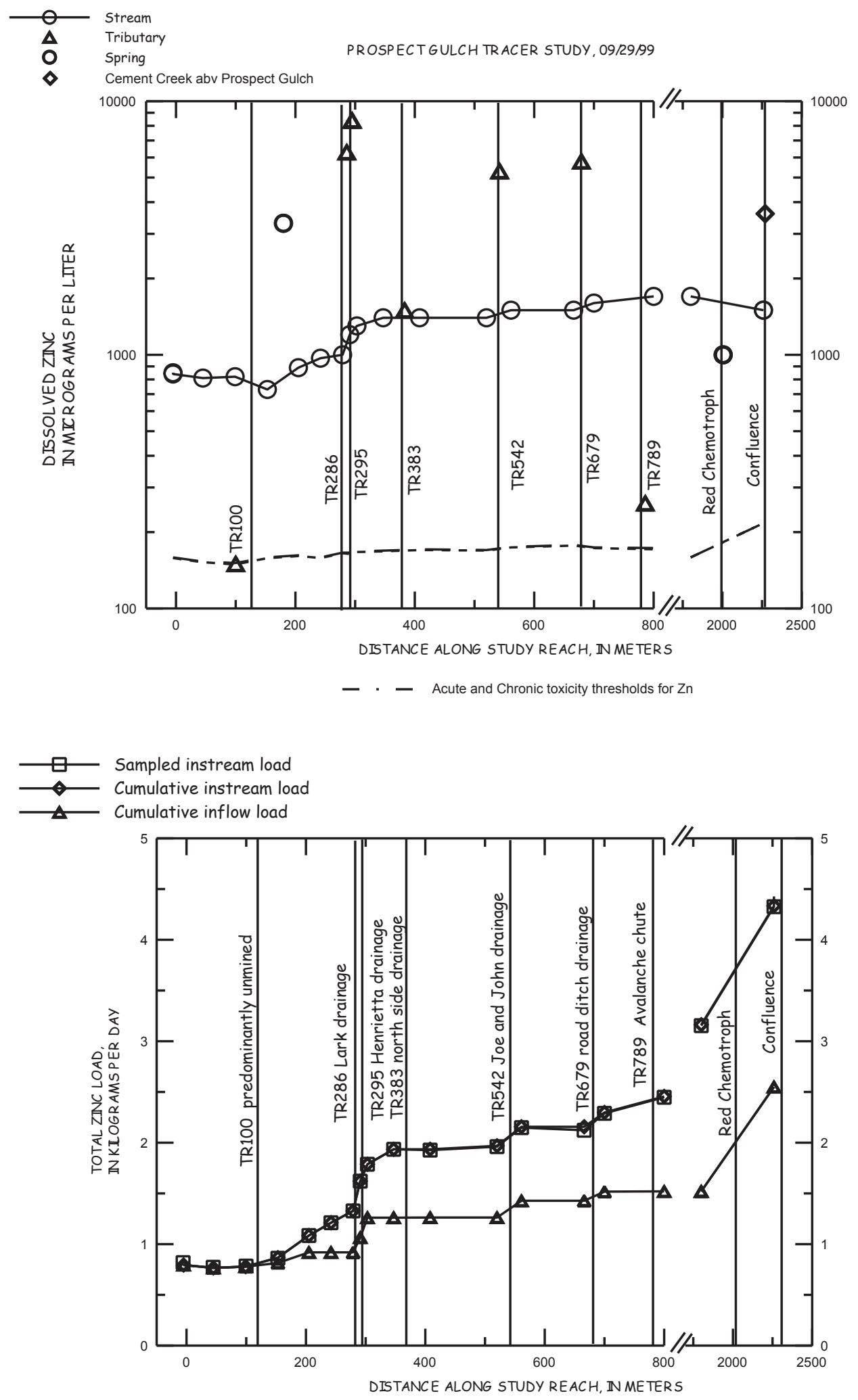

Figure 11. Concentration and load profile of zinc with distance downstream. 
than 2.5 percent of watershed loads for these elements and are within the range attributed to analytical error.

Unsampled inflows-A divergence between the profiles for instream loads and inflow loads generally indicates that there is a considerable amount of subsurface flow that was not unsampled. The difference between cumulative instream load and cumulative inflow load was relatively small for dissolved sulfate and aluminum. For dissolved iron (Fig. 9B), the cumulative inflow load also closely matched the cumulative instream load, except in the Red Chemotroph segment where a difference of about 40 percent occurred. Because only one sample from the Red Chemotroph inflow was sampled over a long reach, the most likely explanation for the difference is that the sampled concentration was not representative of the effective inflow concentration. For example, an oxygenated sample with a relatively high $\mathrm{pH}$ would have already precipitated any dissolved iron; in contrast with unsampled inflow beneath the stream which would probably have a lower $\mathrm{pH}$ and a relatively high amount of dissolved iron.

The difference between the two instream load profiles was greatest for dissolved copper and zinc (Figs. 10B and 11B). Throughout Prospect Gulch (from PG-0 to PG2259) the divergences between the cumulative instream and inflow load profiles for copper and zinc were substantial (Figs. 9B and 10B), indicating an under representation of about 80 percent of the inflow for copper and about 40 percent for zinc. As shown by Table 4, the largest percentage gain in the instream load for copper (155 percent, with an increase in load of $0.13 \mathrm{~kg} /$ day) occurred in the zone of ground-water inflow between PG153 and PG279. The largest load increase for copper of $0.15 \mathrm{~kg} /$ day (31. 4 percent for the reach) occurred between PG800 and PG1800. For the zinc instream load profile, the largest single gain $(1.31 \mathrm{~kg} /$ day $)$ resulted from the large increase in discharge associated with the Red Chemotroph iron spring. The second largest instream gain for zinc $(0.68 \mathrm{~kg} /$ day $)$ occurred in the mine impacted reach between PG279 and PG520. Load increases for copper and zinc were disproportionately higher than increases in discharge for mine- impacted reaches.

In the 800-m detailed reach, there was one flowing tributary (TR100) and only two measurable ground-water inflows and thus the sources of inflows were relatively simple to assess. In the case of the first ground-water inflow near the Lark \#3 and Henrietta \#7 and \#8 mine sites, the density of the sampling network was sufficient to identify the gains in inflow over a 74-m stream segment. The gaining reach begins at PG205 (just downstream of seeps near SP180) as a steep braided reach with no obvious side seeps or tributaries, and is tightly constricted by incised bedrock at $230 \mathrm{~m}$ downstream from the injection site. The 1.7 liters per second $(\mathrm{L} / \mathrm{s})$ increase in ground-water discharge is distributed evenly between samples PG205, PG242, and PG279. As discussed earlier, the stream segment has been greatly disturbed by mining activity on both sides of the channel, thus it is difficult to expose the exact source of groundwater inflow. The most likely explanation is that ground water either is traveling along water-bearing fractures in the bedrock or along the interface between the waste rock and the bedrock, or both. Because the seeps are perennial, ground water probably issues along a deeper water-bearing fracture zone that has been partially buried by waste rock. It is quite likely that mine workings may have followed the fracture zone. The proximity of the Henrietta \#8 mine tunnel to the inflow makes a bedrock fracture connection with the Henrietta mine a distinct possibility. The actual location of the collapsed tunnel could not be definitively determined from field observations. However, one of the more prominent seeps at 193 meters downstream from the injection site appears to have developed across a length of five meters (J.T. Nash, USGS, unpub. field notes, 2000).

Similarly, the second ground-water inflow between PG408 and PG520 is indicated by a gain in perennial flow in the absence of a nearby tributary drainage. The most likely source of the inflow, is either (1) an unmapped water-bearing fracture zone, or (2) shallow alluvial water moving down gradient that encounters exposed bedrock in the streambed. In this reach, there is a relatively thick soil cover material between Prospect Gulch and the road on the north side. Because the other groundwater inflows in the sub-basin are associated with water-bearing fractures, the first scenario is thought most likely.

\section{Principal Sources of Metal Load}

From a watershed perspective, the greatest increases in the most loads occurred in the two lower stream segments (PG800 to PG2259) where little if any mining has occurred. This reach includes the Red Chemotroph spring network, which contributes half of the discharge, 63 percent of the sulfate, 81 percent of the aluminum, 87 percent of the iron, 27 percent of the copper, and 44 percent of the zinc exiting Prospect Gulch. The predominant source of metal loading for this lower reach was weathering of acid-sulfate assemblages containing pyrite. In contrast, the stream reaches most affected by historical mining (PG153 to PG800) accounted for 8 percent of the discharge, 11 percent of the sulfate, 9 percent of the aluminum, 12 percent of the ironó but 59 percent of the copper, and 37 percent of the zinc in the entire Prospect Gulch sub-basin. The percentages of discharge, sulfate, and metal loads for the various reaches are listed in Table 4 and represented as pie charts in Fig. 12.

Loading of sulfate, aluminum, and iron in this highly mineralized sub-basin has more to do with gains in inflow over a given reach than with the extent of historical mining activity. In contrast, the loading of copper and zinc from the 800-m detailed reach is highly disproportionate in comparison with that contributed from the lower reaches of Prospect Gulch where little if any impacts from mining could be identified. Half the discharge, but virtually no copper was contributed downstream from PG1800. Dissolved copper and zinc in natural waters originate mostly from oxidation of vein and disseminated base-metal sulfides such as enargite, zinc-rich tetrahedrite and sphalerite; whereas pyrite oxidation contributes very little in terms of basemetal content (Bove, 2000). 

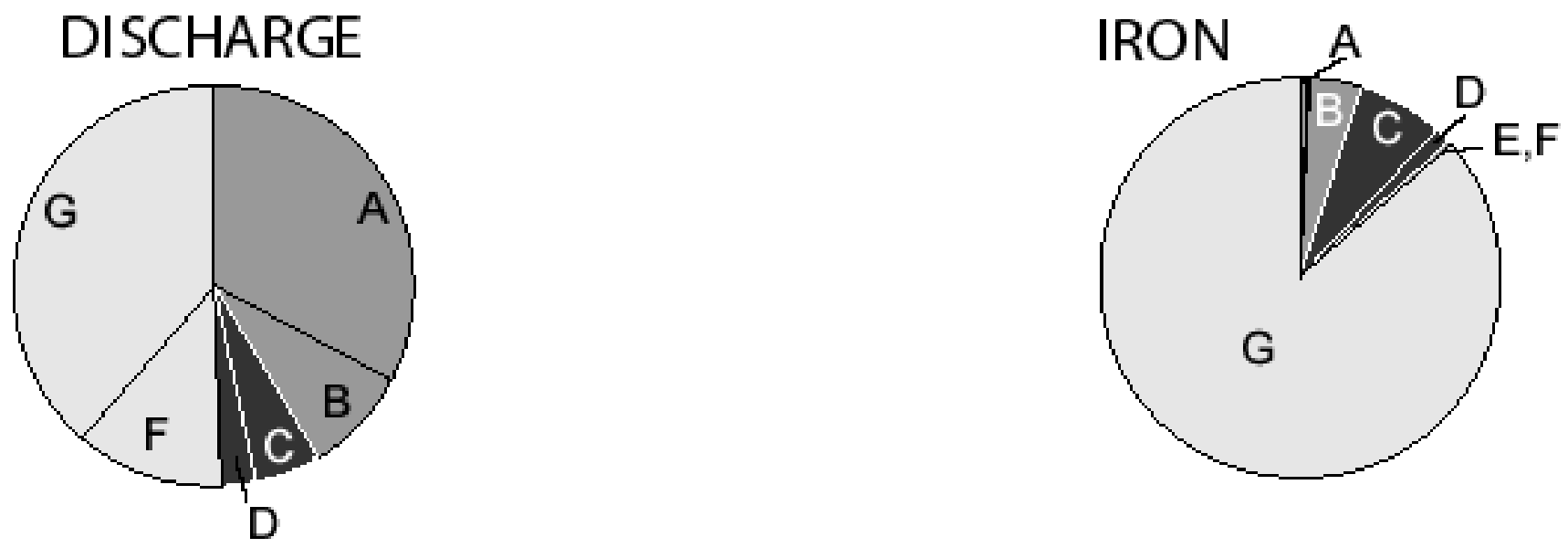

\section{EXPLANATION}

SULFATE

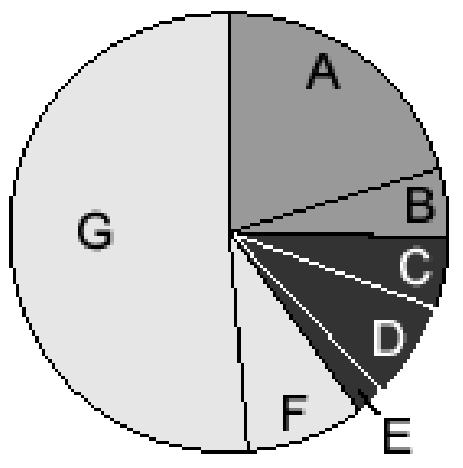

$\mathrm{E}$
A. upstream from PG-5
B. PG-5 to PG153
C. PG153 to PG279
D. PG279 to $P G 520$
E. PG520 to PG800
F. PG800 to PG1800
G. PG1800 to PG2259

COPPER

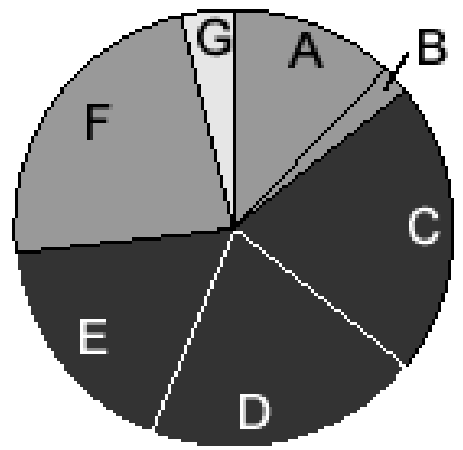

$\square$ indirect effects from mining activites

\section{ALUMINUM receives direct inflows from mines ZINC}
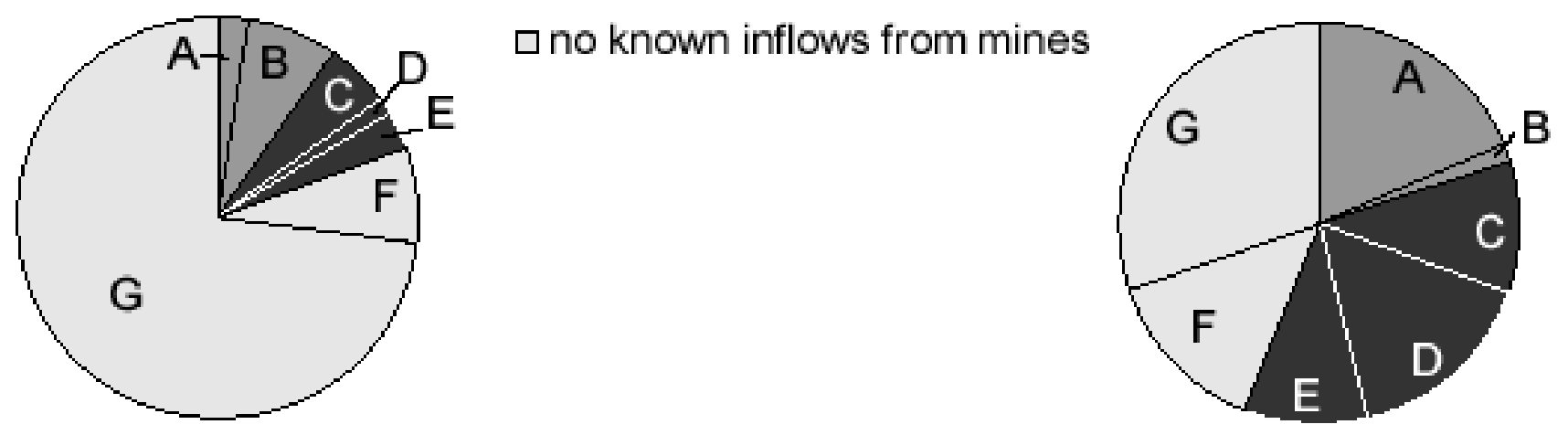

Figure 12. Pie ch arts showing total contribution of discharge, sulfate, alu minum, iron,copper, and zinc by reach in Prospect Gulch, Colorado. 
The greatest increases in loads of copper were near the inactive mine sites and waste dumps. The main sources of the copper to the $800-\mathrm{m}$ reach are adit flows and waste rock talus that was observed within and along the sides of the channel. A plume of waste-rock talus was observed along the channel extending downstream from PG800 toward PG1800. Two hand specimens of waste rock collected in the channel downstream from the Henrietta \# 10 waste dump contained 8 and 15 parts per million (ppm) of copper, respectively (Stan Church, unpub. data). A third sample of streambed sediment in the same reach (sample 97-ABS206) contained 180 ppm of copper. Increases in copper load seem to occur in (1) distinct locations where discharge is increasing; such as downstream from TR100, and between PG205 and PG279, between PG408 and PG520, and above PG1800; and (2) areas where instream copper concentrations are increasing, such as in the vicinity of the Lark-Henrietta waste dumps (PG153 to PG303; and PG700 to PG800).

\section{Relation between Metal Content and Acidity}

The Prospect Gulch water samples can be characterized into broad groups that reflect water-rock interactions with acidsulfate alteration suites of minerals and the degree of mining activity that has occurred. These relations are illustrated by the Ficklin diagram in Fig. 13 (see Ficklin and others, 1992), which plots $\mathrm{pH}$ against the sum of dissolved trace metals $(\mathrm{Cd}+\mathrm{Co}+$ $\mathrm{Cu}+\mathrm{Ni}+\mathrm{Pb}+\mathrm{Zn}$ in $\mu \mathrm{g} / \mathrm{L})$. Samples most impacted by miningó such as adits and inflows discharging from beneath waste dumpsó were characterized by extreme acidity $(\mathrm{pH} \leq 3.0)$ and extreme metal content (sum of dissolved metals $>10,000$ in $\mu \mathrm{g} /$ L). In contrast, regional weathering of pre-acid-sulfate mineral assemblages that were unaffected by mining produced tributary inflows with moderate acidity $(\mathrm{pH}=3.2$ to 5.3$)$ but tended to be moderate to moderately low in dissolved trace metals (sum $<$ $2,000 \mu \mathrm{g} / \mathrm{L})$.

Base flow in Prospect Gulch is a composite of water from both mined and un-mined sources. Upstream from the 800-m study reach, stream flow is relatively low in dissolved trace metals and moderately acidic $(\mathrm{pH} \geq 5.0)$, quite similar to discharge from the Red Chemotroph iron spring. These samples plot near the moderate acid/low metal field of the graph. Samples collected with increasing distance downstream, particularly below the mine-impacted reaches, become more acidic and the dissolved trace-metal content increases, plotting in the high acidity/ high metal field. Tributary inflow TR100 had a highly acidic $\mathrm{pH}$ of 3.9 and relatively low dissolved trace-metal content, probably owing to its higher position in the watershed. Drainage to site TR 100 probably has a shorter composite travel path and less time for water-rock contact in contrast, for example, with ground water supplying the Red Chemotroph spring, which is older and discharges at an elevation that is 2,000 feet $(\sim 0.6 \mathrm{~km})$ lower than site TR100.

Two of the four adit samples (L3P and L3T) plot in the middle of the graph in the high acid/high metal field. These samples are affected by ining to a lesser degree because of reme- diation or dilution. The Lark\#3 adit samples were collected from outside the gated mine tunnel and from the mine drainage pipe following extensive remediation to the site a few weeks before the tracer study. A drainage bulkhead and French drain were installed to reduce drainage through the mine and waste dump. In marked contrast with the extremely acid and extremely high trace-metal content of water from the Henrietta and Joe and John mines, the Lark samples had a $\mathrm{pH}>4.0$ and dissolved trace-metals content $<3,500 \mu \mathrm{g} / \mathrm{L}$. A sample collected prior to remediation on June 30, 1999 had a $\mathrm{pH}$ of 2.7 and sum of dissolved trace-metal content of nearly $70,000 \mu \mathrm{g} / \mathrm{L}$, which would place it in the extreme acid/extreme metal part of the graph. Remediation efforts appear to have lowered acidity and decreased the metal content at this site by at least an order of magnitude. No water was discharging near the gated tunnel on subsequent visits in September 2000 and 2001, therefore this site could not be resampled.

\section{Acute and Chronic Water Quality Standards}

Acute and chronic toxicity thresholds calculated for this study used hardness corrected equations from the State of Colorado Water Quality Control Commission (Colorado Department of Public Health and Environment, 2000). The copper and zinc concentrations for all the stream samples in Prospect Gulch exceeded the calculated acute and chronic toxicity thresholds by an order of magnitude (Figs. 10A and 11A). Only the Red Chemotroph sample, in which the copper concentration was below the analytical detection limit, met the standards for dissolved copper. The acute and chronic standards that were calculated for zinc were nearly identical to one another and overlap in Fig. 11A.

\section{Occurrence and Distribution of Trace-Metals}

In addition to dissolved copper and lead which are present in large concentrations in mine-impacted waters; strontium and less abundant trace metals such as cadmium, cobalt, lithium, nickel, and lead (Table 3) were detected in many of the samples. When a trace element is distinct to a particular rock type, mineral assemblage, or alteration suite; its dissolved concentration is an indication of the history of water-rock interaction along a ground-water flow path. The following metals, discussed in the order they appear in Table 3, yield evidence of drainage patterns from various geologic and anthropogenic sources.

Cadmium-Cadmium has chemical similarities with zinc and is present in zinc ore minerals such as sphalerite (Hem, 1992). Cadmium was present in all four of the mine adit samples, ranging from 9.2 to $54 \mu \mathrm{g} / \mathrm{L}$. Cadmium was also present in all of the down gradient inflows substantially affected by mine drainage (SP180, TR286, TR295, TR543, and TR679), ranging from 14 to $35 \mu \mathrm{g} / \mathrm{L}$. Cadmium was notably absent in inflows that are unaffected by past mining activities (TR100, TR786, and RC2005). Cadmium concentrations were greatest in inflows associated with drainage from the Lark \#3, Henrietta \#7 and \#8, and Joe and John mines. 
PROSPECT GULCH, UPPER ANIMAS WATERSHED, COLORADO

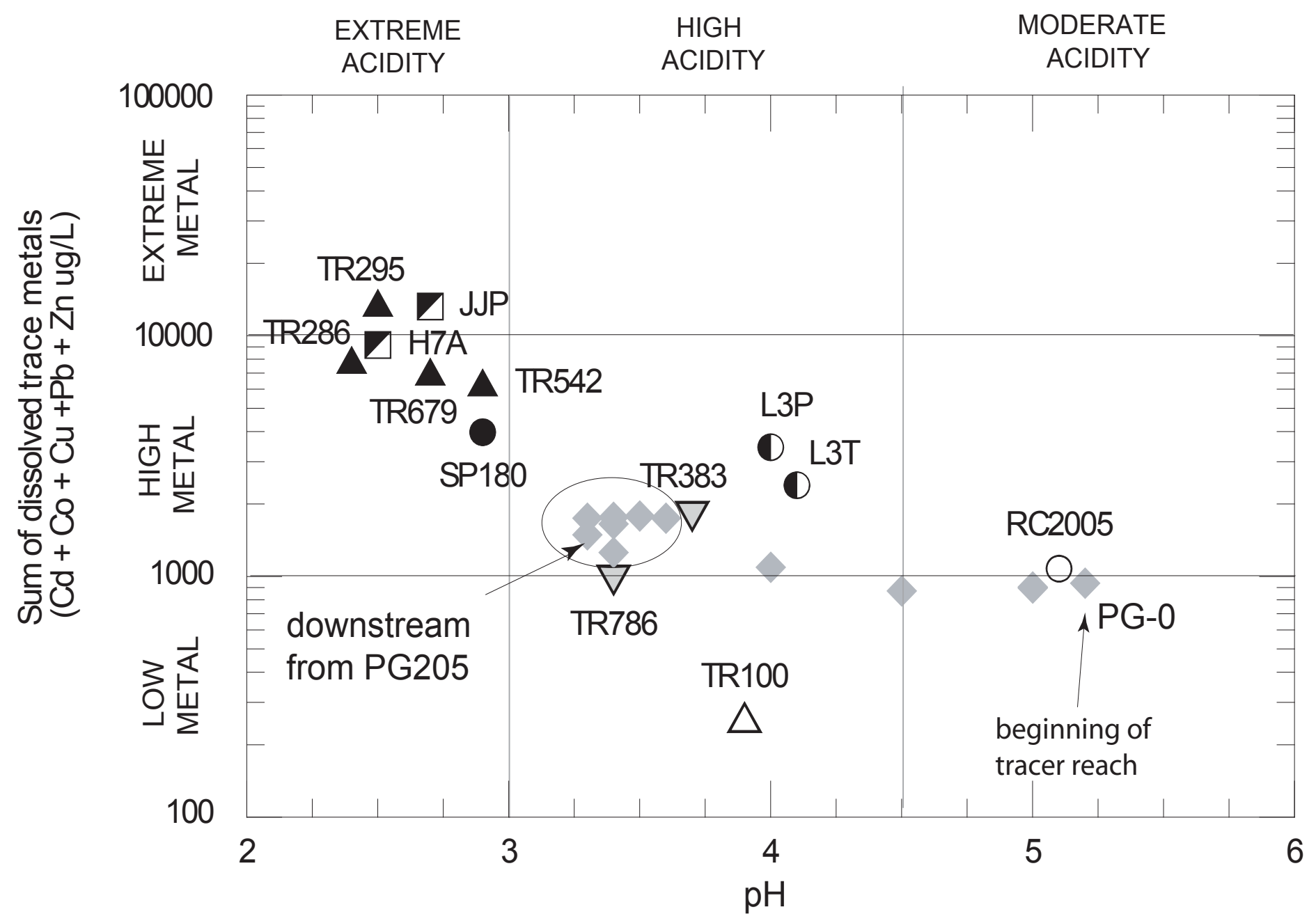

\begin{tabular}{|c|c|}
\hline & EXPLANATION \\
\hline$\diamond$ & base flow in Prospect Gulch \\
\hline \multicolumn{2}{|c|}{ Sites directly impacted by mine drainage: } \\
\hline$\square$ & adit \\
\hline D & remediated adit \\
\hline O & spring draining through waste dump \\
\hline$\Delta$ & tributary receiving adit drainage \\
\hline \multicolumn{2}{|c|}{ Sites indirectly impacted by mine drainage: } \\
\hline$\nabla$ & tributary with upgradient mine impacts \\
\hline \multicolumn{2}{|c|}{ Background sites: } \\
\hline$\triangle$ & TR100 tributary \\
\hline$\bigcirc$ & Red Chemotroph spring \\
\hline
\end{tabular}

Figure 13. Geochemical classification (adapted from Ficklin and others, 1992) showing the relation between $\mathrm{pH}$ and dissolved trace-metal content in mine adits, springs, tributary seeps, and base flow in Prospect Gulch. 
Cobalt - The occurrence of detectable dissolved cobalt in Prospect Gulch is widespread because cobalt commonly occurs as a trace constituent in pyrite. Cobalt was detected in all of the sampled springs, tributaries, and mine adits, except the two most dilute samples from the Lark \#3 drainage pipe (site L3P) and the TR786 avalanche chute. The highest cobalt concentration of 170 $\mu \mathrm{g} / \mathrm{L}$ was measured in a sample from the Henrietta \#7 adit (site H7A). The second highest concentration of $89 \mu \mathrm{g} / \mathrm{L}$ was directly down gradient at site TR295. The third highest concentration of $42 \mu \mathrm{g} / \mathrm{L}$ was from the Red Chemotroph iron bog.

Lithium - Dissolved lithium is relatively rare in most waters (Hem, 1992) and was below detection in all but a few of the samples analyzed. Dissolved lithium in Prospect Gulch is probably derived from anthropogenic sources such as chemical agents such as foams used to block seepage to the portal during remediation of the Lark \#3 mine adit or possibly from $\mathrm{LiBr}$ tracers used in other tracer studies as a contaminant on sampling equipment. The highest concentration of $270 \mu \mathrm{g} / \mathrm{L}$ of lithium was from the Lark \#3 adit (L3T) and the second highest concentration of $38 \mu \mathrm{g} / \mathrm{L}$ was directly down gradient at site TR286. Lithium was also detected in the Henrietta \#7 adit $(17 \mu \mathrm{g} / \mathrm{L})$, and was measured at the detection limit $(10 \mu \mathrm{g} / \mathrm{L})$ where the Henrietta adit drainage enters Prospect Gulch (TR295). A trace of lithium $(12 \mu \mathrm{g} / \mathrm{L})$ was detected in the sample from the Red Chemotroph.

Nickel-Nickel was similar in its distribution to cobalt. The highest nickel concentration of $110 \mu \mathrm{g} / \mathrm{L}$ was for a sample from the Henrietta \#7 adit (H7A). The second highest concentration of $56 \mu \mathrm{g} / \mathrm{L}$ was from tributary inflow TR295, which receives Henrietta \#7 adit flow. The third highest concentration of $32 \mu \mathrm{g} / \mathrm{L}$ was a sample from the Red Chemotroph iron bog. Nickel was present in all of the sampled springs, tributaries, and mine adits, except for the drainage from the Lark \#3 pipe (site L3P), TR383, and the TR786 avalanche chute.

Lead-Lead occurs in vein and disseminated base-metal sulfides such as enargite. The highest lead concentration of $1,400 \mu \mathrm{g} / \mathrm{L}$ was for a sample from the Joe and John mine adit (site JJP). The second and fourth highest concentrations of 490 and $96 \mu \mathrm{g} / \mathrm{L}$ were for tributary inflow from samples TR679 and TR542, respectively. Both of these tributaries receive drainage from the Joe and John mine. The third and fifth highest concentrations of 97 and $81 \mu \mathrm{g} / \mathrm{L}$ were from samples from the Lark \#3 mine adit (site L3P) and the sample directly down gradient at TR286, respectively. Lead was not detected in samples from the Henrietta \#7 adit or from Henrietta tributary TR295; it was also absent in the TR786 and the Red Chemotroph iron spring samples.

Strontium-Strontium commonly substitutes for calcium (Ca) in the chemical lattices of many minerals. In Prospect Gulch it is primarily derived from dissolution of secondary calcium-bearing minerals such as gypsum and calcite. Calcite occurs as a replacement mineral in fractures in propylitic rocks; whereas gypsum is more widely distributed in veins and fractures of different alteration assemblages. Strontium values for all of the sampled inflows, including the mine adits, range from 23 to $610 \mu \mathrm{g} / \mathrm{L}$.

Concentrations of strontium were highest in the uppermost reaches draining the southern part of the sub-basin where there is more propylitic alteration. Strontium concentrations in upper Prospect Gulch were diluted with distance downstream by inflows with lower strontium concentrations that emanate from more hydrothermally-altered areas. Prospect Gulch had a strontium concentration of $1,100 \mu \mathrm{g} / \mathrm{L}$ at the beginning of the 800 meter study reach and $640 \mu \mathrm{g} / \mathrm{L}$ near its confluence with Cement Creek. Samples from the two largest perennial tributary inflows, the Red Chemotroph iron spring and TR100, had strontium concentrations of 410 and $240 \mu \mathrm{g} / \mathrm{L}$, respectively.

The occurrence and distribution of these dissolved trace metals can be related to drainage from specific areas. In general, concentrations of base metals were greatest near the mined ore bodies, but were sometime present in inflow discharging from large fracture networks. Samples associated with drainage from the Lark mine were elevated in cadmium, lithium, and lead. Samples associated with drainage from the Henrietta \#7 adit were elevated in cadmium, cobalt, lithium, and nickel. Samples associated with drainage from the Joe and John mine were elevated in cadmium, cobalt, nickel and lead. The flowing tributary TR100 had measurable cobalt and nickel. And the Red Chemotroph inflow contained cobalt, lithium, and nickel. All of the inflow samples were depleted in strontium relative to the stream samples, however, the presence of cobalt and nickel in inflow samples was fairly ubiquitous. Elevated concentrations of lead were predominantly found in samples associated with drainage from the Joe and John mine, and to a lesser degree from the Lark mine. Only cadmium was uniquely associated with samples collected from sites affected by drainage from the Lark, Henrietta, and Joe and John minesó and absent in all samples thought to be largely unaffected by mining activities. Thus cadmium appears to be an important indicator of mining contamination in this environmental setting.

\section{CONCLUSIONS}

Using tracer injection and synoptic sampling, we quantified inflow loads of metals along a 2,259-m reach of Prospect Gulch. Prospect Gulch provides an excellent analogue for a highly mineralized watershed that delivers ground water from multiple sources, some of which apparently have no influence from mining activity and some of which clearly have been affected by past mining activities to varying degrees.

The sampled inflows can be classified by $\mathrm{pH}$ and dissolved trace-metal content into geochemical groups that reflect waterrock interactions with acid-sulfate alteration suites of minerals in the watershed and the degree of mining activity that has occurred. Samples most impacted by mining were characterized by some of the lowest $\mathrm{pH}$ values and highest concentrations of aluminum, sulfate, and iron; but also contained elevated trace metals from hydrothermally-altered vein minerals including 
copper, zinc, cadmium, nickel, and lead. Regional weathering of pre-acid-sulfate mineral assemblages produces moderately low pH waters also elevated in aluminum, sulfate, and iron; but generally lacking in trace metals such as copper, cadmium, nickel, and lead.

Water in contact with regionally altered rocks can be moderately or even highly acidic ( $\mathrm{pH}$ in this study ranged from 3.2 to 5.3) but tends to be relatively low in dissolved metals except for for zinc (sum of the dissolved metals $\mathrm{Cd}+\mathrm{Co}+\mathrm{Cu}+\mathrm{Ni}+\mathrm{Pb}+$ $\mathrm{Zn}$ tended to be $\leq$ about $1,000 \mu \mathrm{g} / \mathrm{L}$ ). Although water quality generally exceeds toxicity thresholds for aquatic life, the poor water quality is largely natural in origin and probably pre-dates any mining activity. Examples of water samples that are affected primarily by natural acid weathering of hydrothermal alteration products include samples from tributary TR100 and the Red Chemotroph iron spring (RC2005).

The most highly-degraded water emanates from areas that were originally mineralized to a greater degree and contain more vein and disseminated base-metal sulfidesó and which generally were disturbed to some degree by historical mining activities. The proprietors of the Lark, Henrietta, and Joe and John mines targeted the mineralized veins that were elevated in silver and base metals. Before mining, baseline concentrations of dissolved metals in the $800-\mathrm{m}$ reach were probably elevated compared with drainage from nearby areas that were less mineralized and had undergone less alteration. Although water quality at the beginning of the tracer reach is not pristine or representative of background conditions, pre-mining water quality of tributary inflows in the detailed study reach was probably similar to that of sites PG-0 and TR100, having moderately low pH between about 3.9 and 5.2 and metal content $\leq 1,000 \mu \mathrm{g} / \mathrm{L}$. Extreme acidity and extreme trace-metal content $(\mathrm{pH}<3$ and sum of dissolved metals $>10,000 \mu \mathrm{g} / \mathrm{L}$ ) is related to direct drainage from mined areas (for example, mine-impacted samples TR286 and TR295); discharge of drainage from mine adits (samples H7A and JJP); and subsurface drainage of waste rock in close proximity to the stream (seep SP180), as illustrated by Fig. 13. Local remediation efforts appear to have lowered acidity and substantially decreased metal content, as shown by samples from the Lark mine (L3T and L3P). In marked contrast with the other adit samples from the Henrietta and Joe and John mines, these samples had a $\mathrm{pH}>4.0$ and dissolved metals content $<3,500 \mu \mathrm{g} / \mathrm{L}$. Samples TR383 and TR786 appear moderately impacted by nonpoint drainage from upgradient mining activity, having intermediate $\mathrm{pH}$ between 3.0 and 4.0 and a sum of dissolved metals between 900 and 2,000 $\mu \mathrm{g} / \mathrm{L}$.

Changes in stream discharge are closely related to geologic features. During the low-flow conditions of the tracer study, large structural features such as faults and fracture networks were the dominant control on the hydrology and accounted for most of the inflows. The largest water-bearing fractures carry composite drainage from different mineral assemblages to specific stream segments, sometimes over considerable distances. Changes in inflow chemistry broadly corresponded with the degree of mineral alteration in the basin, as well as with drainage from areas that have been impacted by mining.

Occurrences of dissolved trace metals were helpful in identifying ground-water flow paths of tributary inflows. Cadmium, in particular, was notably absent in inflows that are unaffected by past mining activities and greatest in inflows associated with drainage from the Lark \#3, Henrietta \#7 and \#8, and Joe and John mines. The occurrence of cobalt and nickel was fairly ubiquitous, but the greatest concentrations occurred in adit flows from mined ore bodies. Strontium (which occurs in gypsum as a vein fill mineral and is most abundant in the propylitically altered areas) was highest in the headwaters of Prospect Gulch and steadily decreased by dilution with increasing distance downstream.

The largest single source of sulfate, iron, aluminum, and zinc to Prospect Gulch was the spring network associated with the Red Chemotroph, located about 250 meters upstream from the confluence with Cement Creek. The spring network supplying the iron bog (and inflows that emanate from above PG1800 to the mouth) supplies half of the total base-flow discharge at the mouth of Prospect Gulch. A linear fracture network connects the iron spring with upgradient exposures of hydrothermally altered rocks, including quartz-sericite-pyrite and quartzpyrophyllite assembleges. These rocks are exposed along the northeast ridge of the sub-basin. Because the Red Chemotroph sample had $1,000 \mu \mathrm{g} / \mathrm{L}$ of dissolved zinc and $<10 \mu \mathrm{g} / \mathrm{L}$ of dissolved copper (compared with 1,700 and $360 \mu \mathrm{g} / \mathrm{L}$ in the adjacent stream, respectively), the downstream concentrations of these constituents are diluted substantially in Prospect Gulch. However, because discharge increased by 36 percent near the iron spring, which contained zinc but no detectable copper, the sampled instream load for zinc increased by 43 percent, while the instream load of copper remained constant throughout the reach (PG1800 to PG2259).

The most heavily mine-impacted reach (PG153 to PG800), contributed 8 percent of the discharge, and 11, 9, and 12 percent of the sulfate, aluminum, and iron loads in Prospect Gulch, respectively. In contrast, natural acidic drainage associated with the Red Chemotroph iron spring yielded 39 percent of the discharge and a substantial 54, 73, and 87 percent of the sulfate, aluminum, and iron loads in Prospect Gulch. These statistics illustrate that loading of sulfate, aluminum, and iron is more closely correlated with the gain in discharge over a given reach and the type of rocks present than with the extent of historical mining activity. In marked contrast, the loading of copper and zinc from the 800-m detailed reach is highly disproportionate in comparison with the small gain in discharge. Fifty-nine percent of the copper loading and 37 percent of the zinc loading at the mouth occurred between PG153 and PG800, compared with only 8 percent of the discharge. Half the discharge but no measurable gain in copper was contributed between PG1800 and the mouth of Prospect Gulch. Dissolved copper and zinc in natural waters originate mostly from oxidation of vein and disseminated base-metal sulfides such as enargite, zinc-rich tetrahedrite and sphalerite; whereas natural acid drainage from pyrite oxida- 
tion contributes very little in terms of base-metal content. Contributions of cadmium, nickel, and lead also were present in tributary inflows to this reach.

Based on the sampled instream loads of Kimball and others (in press) for Cement Creek, base flow from Prospect Gulch contributes about 4.8 percent of the total discharge at the mouth of Cement Creek; compared with 1.8, 8.8, 15.9, 28, and 8.6 percent of the sulfate, aluminum, iron, copper and zinc loads, respectively. Given the enormous loads from the Red Chemotroph iron spring, however, remediation is likely to have little impact on loading of sulfate, aluminum, and iron from Prospect Gulch to Cement Creek. Remediation of mine sites such as the Lark and Henrietta mines in the detailed study reach may potentially reduce sub-basin loads of copper and to a lesser extent zinc; as well as other base metals such as cadmium, nickel, and lead. An added benefit of remediation is that a small increase in the $\mathrm{pH}$ in the most heavily mine-impacted reach might lower the solubility of $\mathrm{pH}$-sensitive metal species downstream.

Whether remediation of abandoned mines in Prospect Gulch can be successful depends on how remediation objectives are defined. For example, if the goal of cleaning up abandoned mine sites is to increase $\mathrm{pH}$ and reduce inflow loads (and pointsource concentrations) of copper, zinc, and other trace base metals in Prospect Gulch, then local and downstream improvements may be feasible. Moreover, public safety and aesthetic benefits from mine cleanup are certainly worth considering. If the primary goal, however, is to substantially reduce loads of sulfate, aluminum, and zinc to Cement Creek and the Upper Animas River, any remedial activities will be an expensive failure because the major source of these contaminants is natural in origin and largely unrelated to mining. Improved understanding of the site-specific geochemistry, structural geology, and hydrologyó in conjunction with quantification of metal loads by the tracer injection approachó can allow more informed decisions about remediation of abandoned mines on both a sub-basin and a larger watershed scale.

Acknowledgements - This work was supported by U.S. Geological Survey Abandoned Mine Lands Program and the Bureau of Land Management. Barbara Hite, Jon Evans, Alisa Mast, Winfield Wright, Alan Duran, Bill Carey, Tracy Sole and Lynn Padgett provided invaluable assistance with the synoptic sampling. Alisa Mast and Paul Briggs analyzed major and trace chemistry using ICP-AES. Peter Theodorakas provided IC analysis of chloride and sulfate. Reviews by Katie Walton-Day, Stan Church, and Rob Robinson helped to greatly improve this manuscript.

\section{REFERENCES CITED}

Bencala, K.E., and McKnight, D.M. (1987) Identifying instream variability: sampling iron in an acidic stream. In Chemical Quality of Water and the Hydrologic Cycle (eds. R.C. Averett and D.M. McKnight), 255-269. Lewis Publishers, Inc.
Bencala, K.E., McKnight, D.M., and Zellweger, G.W. (1990) Characterization of transport in an acidic and metal-rich mountain stream based on a lithium tracer injection and simulations of transient storage. Water Resources Research 23, 989-1000.

Bove, D.J., Wright, W.G. , Mast, M.A. and Yager, D.B. (1998) Natural contributions of acidity and metals to surface waters of the upper Animas River watershed, Colorado. In Science for watershed decisions on abandoned mine lands: Review of preliminary results. (eds. P. von Guerard and D.A. Nimick) February 4-5, 1998. U.S. Geological Survey Open-File report 98-297.

Bove, D.J., Mast, M.A., Wright, W.G. , Verplank, P.L., Meeker, G. P., and Yager, D.B. (2000) Geologic Control on acidic and metalrich waters in the Southeast Red Mountains area, near Silverton, Colorado. ICARD 2000: Proceedings for the Fifth International Conference on Acid Rock drainage, Vol. I, 523-534.

Burbank, W.S., and Luedke, R.G. (1969) Geology and ore deposits of the Eureka and adjoining districts San Juan Mountains, Colorado: U.S. Geological Survey Professional Paper 535.

Colorado Department of Public Health and Environment (2000) The basic standards and methodologies for surface water, regulation no. 31 (5 CCR 1002-31): Denver, Colorado, Department of Public Health and Environment, water Quality Control Commission, 53-54.

díAngelo, W.M. and Ficklin, W.H. (1996) Fluoride, chloride, nitrate, and sulfate in aqueous solution by chemically suppressed ion chromatography In Analytical methods manual for the Mineral Resources Surveys Program (ed. B.F. Arbogast), U.S. Geological Survey Open-File Report 96-525, 149-153.

Drever, J.I. (1988) The Geochemistry of Natural Waters: Prentice Hall, Englewood Cliffs, New Jersey, 379.

Ficklin, W.H., Plumlee, G. S., Smith, K. S., and McHugh, J.B. (1992) Geochemical classification of mine drainages and natural drainages in mineralized areas: in Proceedings of the 7th international symposium on water-rock interaction; Kharaka, Yousif K. (ed.), Maest, Ann S. (ed.), v. 1, Low temperature environments, 381384.

Hem, J.D., (1992) Study and interpretation of the chemical characteristics of natural water: U.S. Geological Survey Water-Supply Paper 2254, 263.

Herron, J., Stover, B.and Krabacher, P. (1998) Cement Creek reclamation feasibility report, upper Animas River Basin, Colorado Division of Minerals and Geology, Denver, Colorado, 76-80.

Kimball, B. A., Broshears, R. E., Bencala, K. E., McKnight, D. M. (1994) Coupling of hydrologic transport and chemical reactions in a stream affected by acid mine drainage. Environmental Science \& Technology, ES \& T, 28 (12), 2065-2073.

Kimball, B.A. (1997) Use of tracer injections and synoptic sampling to measure metal loading from acid mine drainage. U.S. Geological Survey, Fact Sheet FS 0245-96. 
Kimball, B. A., Runkel, R. L., Walton-Day, Katherine, and Bencala, K. E. (1998) Integration of mine-drainage effects in watersheds using tracer injections and synoptic sampling: In Science for watershed decisions on abandoned mine lands; review of preliminary results, (Nimick, David A. and von Guerard, Paul, eds.), U.S. Geological Survey Open-File Report 98-0297.

Kimball, B.A., Bencala, K.E., and Runkel, R. L., (2000) Quantifying effects of metal loading from mine drainage. In ICARD 2000: Proceedings for the Fifth International Conference on Acid Rock drainage, Vol. II, 1381-1390.

Kimball, B. A., Runkel, R. L., Walton-Day, Katherine, and Bencala, K. E. (2001) Assessment of metal loads in watersheds affected by acid mine drainage by using tracer injection and synoptic sampling: Cement Creek, Colorado, USA. Accepted for publication in Applied Geochemistry.

LaMothe, P.J., Meier, A.L., amd Wilson, S. (1999) The determination of forty four elements in aqueous samples by inductively coupled plasma mass spectrometry: U.S. Geological Survey Open-File Report 99-151, 1-14.

Lipman, P.W., Fisher, F.S., Mehnert, H.H., Naeser, C.W., Luedke, R.G., and Steven, T.A. (1976) Multiple ages of mid-Tertiary mineralization and alteration in the western San Juan Mountains, Colorado: Economic Geology, v. 71, 571-588.

Lipman, P.W., Steven, T.A., Luedke, R.G., and Burbank, W.S. (1973) Revised volcanic history of the San Juan, Uncompahgre, Silverton, and Lake City calderas in the western San Juan Mountains, Colorado: U.S. Geological Survey Journal of Research, v. 1, 627642 .

Mathsoft, Inc. (1999) S-PLUS guide to statistics, volume 2: Seattle, Wash., Mathsoft, Inc., 1-24.

Nash, J.T. (1999) Geochemical Investigations and Interim Recommendations for Priority Abandoned Mine Sites, BLM Lands, upper Animas Watershed, San Juan County, Colorado U.S. Geological Survey Open-File Report 99-323, 45.

Nimmick, D. A., and von Guerard, P. (1998) Science for watershed decisions on abandon mine landsó review of preliminary results: U.S. Geological Survey Open-File Report 98-297.

Rantz, S.E., and others (1982) Measurement and computation of streamflow: Volume 1. Measurement of stage and discharge: U.S. Geological Survey Water-Supply Paper 2175, Chapter 7 Measurement of discharge by tracer dilution, p. 211-259.

Wirt, Laurie, Leib, K.J., Bove, D.J., Mast, M.A., Evans, J.B., and Meeker, G.P. (1999) Determination of chemical-constituent loads during base-flow and storm-runoff conditions near historical mines in Prospect Gulch, upper Animas River watershed, southwestern Colorado, U.S. Geological Survey Open-File Report 990159, 39 .

Wirt, Laurie, Leib, K.J., and Mast, M.A. (2000) Chemical-constituent loads during thunderstorm runoff in a high-altitude alpine stream affected by acid mine drainage: ICARD 2000: Proceedings for the Fifth International Conference on Acid Rock drainage, Vol. II, 1391-1401.
Yager, D.B., and Quick, J.E. (1993) SuperXap Manual: U.S. Geological Survey Open-File Report 93-12, 45. 